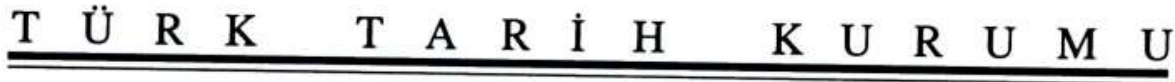 BELLETEN
}

\section{BÜYÜK MENDERES HAVZASINDA PREHISTORIK YERLEŞIM DOKUSU}

\section{ENGIN AKDENIZ*}

\section{COĞRAFYA:}

Ege Bölgesi'nin en uzun akarsuyu olan Büyük Menderes Irmağı, DinarSandıklı arasındaki dağlık arazide doğar. Burada bulunan kaynak kollarından biri Dinar'ın hemen kuzeydoğusundaki kireç taşı dikliklerinde yer alan karstik kökenli Antik Çağ'ın ünlü Marsyas kaynağından doğan koldur. Marsyas kaynağı çoğu zaman Büyük Menderes'in başlangıcı sayılır. Daha uzun olan ikinci kol ise Sandıklı Ovası'nı çeviren yüksek dağlardan inen derelerin birleşmesinden oluşur. Çivril Ovası'na kavuşan bu ikinci kol Büyük Menderes adını alır. Bir süre aynı ovanın ekseni doğrultusunda aktıktan sonra Çal'da keskin bir dirsek yaparak batıya döner ve üçüncü bir kaynak olan Banaz Çayı ile birleşir. Günümüzde bu birleşme Banaz Çayı olarak adlandırılmaktadır. Büyük Menderes daha güneyde Sarayköy yakınlarında kendi adını taşıyan çöküntü ovasına girer. Honaz Dağı eteklerini izleyerek gelen Aksu Çayı'nı da aldıktan sonra genellikle ovanın güney kenarına yakın ve yaklaşık 200 km. uzunluğunda bir çığır izler. Dandalas Çayı'na (Morsynos) ek olarak Menteşe yöresi dağlarından gelen Akçay (Harpasos) ve Çine Çayları (Marsyas) da sularını Büyük Menderes Irmağı'na boşaltır. Bu akarsular dışında havzada sularını Büyük Menderes Irmağı'na boşaltan 50'den fazla akarsu, dere ve çay vardır ${ }^{1}$. Irmak $600 \mathrm{~km}$. uzunluğunda olup yaklaşık 25.000

*Yrd. Doç. Dr., Engin Akdeniz, Adnan Menderes Üniversitesi, Fen-Edebiyat Fakültesi, Protohistorya ve Önasya Arkeolojisi Anabilim Dal, Aydın

${ }^{1}$ Göney $1975,56$. 
$\mathrm{km}^{2}$ 'lik bir alanı dolaşarak Ege Denizi'ne ulaşır. Irmağın ortalama debisi saniyede $110 \mathrm{~m}^{3}$ dolayındadır. Ençok su getirdiği aylar Ocak ve Şubattır (ortalama saniyede $164 \mathrm{~m}^{3}$ ). Bol yağışlı yıllarda debisinin $300 \mathrm{~m}^{3}$ 'e çıktığı da olmuştur. Buna karşılık yazın çok azahır (Ağustos'ta $12 \mathrm{~m} 3$ ).

Büyük Menderes Havzası olarak adlandırılan ve Büyük Menderes Irmağı'nın doğduğu yerden denize döküldügü kesime kadar uzanan alan ile çevresini oluşturan bölge, coğrafi özellikleri dolayısıyla genel olarak Aşağı Büyük Menderes, Orta Büyük Menderes ve Yukarı Büyük Menderes olmak üzere üç kısma ayrılır. Ancak Orta Büyük Menderes ayırımı özellikle coğrafyacılar tarafindan kabul edilmemekte, bu bölümün toprakları da Aşağı Büyük Menderes kapsamında ele alınmaktadır.

\section{BÖLGEDE YAPILAN PREHISTORYA AMAÇLI ARAŞTIRMALAR:}

Yöredeki Prehistorik yerleşimlere yönelik araşturmalar Klasik Arkeolojiyle ilgili olanlara oranla oldukça geç tarihlerde başlamıştur. 18. yüzyıldan itibaren araşturmacıların ilgisi antik kentler üzerinde yoğunlaşmış, hatta buralarda kazılar yapılmıștur. Havzada ilk prehistorik kazı 1935-1937 yılları arasında Lamb tarafından Kusura'da gerçekleştirilmiştir ${ }^{2}$. Kusura kazıları Batı Anadolu'nun prehistoryasını tanımayı sağlayan ilk araştırmalardandır.

Mellaart'ın 1951-1954 ylları arasında Güneybat Anadolu'da geniş bir alanda yürüttüğü yüzey araşturmaları da bölge prehistoryasının anlaşılmasına yardımcı olmuş önemli bir çalışmadır ${ }^{3}$. Ancak, bu araştırmada havzanın aşağı ve orta kesimleri incelenmemiş, dolayısıyla havzanın sınırlı bir bölümü ele alınmıştur. French'in 1959 ve 1960 'da İzmir, Manisa, Aydın ve Denizli illerinin bir bölümünde gerçekleştirdiği yüzey araşturmalarında Büyük Menderes Havzası'nda yalnızca üç yerleşim incelenmiş olmasına karşın yerleşimlerin oldukça erken dönem özelliklerini yansıtması ve bunlardan Hamidiye'nin günümüzde yok olması sebebiyle önem taşımaktadır ${ }^{4}$. Mellaart'ın Lloyd ile birlikte 1954-1956 yılları arasında sürdürdüğü Beycesultan kazıları sayesinde havzanın olduğu kadar tüm Güneybatı Anadolu'nun da prehistoryası şekillenmeye başlamışur ${ }^{5}$. Kazıda uygulanan bazı yöntem ve sonuçlar tartış-

${ }^{2}$ Lamb 1937, 1 vd.; Lamb 1938, 217 vd.

${ }^{3}$ Mellaart 1954, 175 vd.

4 D. French, "Early Pottery Sites from Western Anatolia", Bulletin of the Institute of Archaeology 5 (1965), 15 vd.

${ }^{5}$ Mellaart 1955, 39 vd.; Lloyd-Mellaart 1962, 1 vd.; Lloyd-Mellaart 1965, 1 vd. 
malı olsa da ortaya çıkarılan mimari kalıntılar, küçük buluntular Güneybatı Anadolu'nun kültürel yapısının anlaşılmasına büyük katkıda bulunmuştur. Kazılar sırasında çevrede sürdürülen yüzey araştırmalarında saptanan yerleşimler kültürel yayılımı bir ölçüde gözler önüne sermiştir. Havza genelindeki toplam 129 yerleşimden önemli bir bölümü, belki de 3/2'si bu kazı sırasındaki yüzey araşurmalarında incelenmiştir.

Havzada kazısı yapılan üçüncü prehistorik merkez Aphrodisiasdır ${ }^{6}$. Burada Pekmeztepe, Akropolis ve sınırlı olarak Kuşkalesi'nde yürütülen kazılar, genel özellikleriyle Beycesultan'a benzese de kendine özgü niteliklere sahip bir kültürle karşı karşıya kalındığını göstermiştir. Ayrıca yine bu dönemde Dandalas Vadisi'nde gerçekleştirilen yüzey araşurmalarında bazı prehistorik yerleşimler ilk kez incelenmiştir ${ }^{7}$. Aphrodisias'ın güneydoğusunda, Tavas yakınlarında yer alan Karahisar Höyük'te 1985 yılında yapılan Müze kazısı da yöre kültürünün anlaşılmasını sağlamıştır ${ }^{8}$. Bu kazıdan çıkarılan eserlerle Karacasu çevresinde bulunan ve büyük bölümü yayınlanmayan eserler, tarafimızdan değerlendirilmektedir. Orta Büyük Menderes'deki bir başka yerleşim olan Yassı Höyük'de 1997 yılında başlatılan kurtarma kazısı sonuçları ise henüz tüm olarak yayımlanmamıştur ${ }^{9}$.

Prehistorik kazıların yapıldığı Kusura ve Beycesultan, havzanın yukarı kesimlerinde, Aphrodisias ise orta kesimlerinde yer almaktadır. Aphrodisias'dan Miletos'a kadar uzanan geniş coğrafyada ve aradaki Akçay, Çine Çayı vadilerinde prehistorik dönemlere yönelik hiçbir kazı gerçekleştirilmemiştir. Böylece bu bölgenin kültürel durumu yüzey araştırmalarıyla anlaşılmaya çalışılmıştır. Bu boşluğu doldurmak amacıyla 1995 yılında yaptığımız yüzey araşturmalarında önemli sonuçlar elde edilmiş olsa da söz konusu alanda uzun süreli yeni yüzey araştırmalarına ve tabaka kazılarına ihtiyaç vardır ${ }^{10}$.

Aphrodisias'dan daha batıda prehistorik tabakaların kazıldığı iki yerleşim Miletos ve Didymadır ${ }^{11}$. Zamanında Büyük Menderes Havzası üzerindeki

${ }^{6}$ Joukowsky 1986a, 1 vd.; 1986 b, 1 vd.; Joukowsky 1987, 31 vd.

${ }^{7}$ Leurquin 1986, $725 \mathrm{vd}$.

${ }^{8}$ Eski Eserler ve Müzeler Bülteni 8 (1986), 27-28

${ }^{9}$ R.Duru, "Yassıhöyük Kazıları 1997", Eskiçağ Bilimleri Enstitüsü Dergisi Sayı 5 (1998), 17; R.Duru, "1997 Yilında Yassıhōyük'te Yapılan Kazılar Hakkında Rapor", XX. KST I, Ankara 1999, 131 vd.

${ }^{10}$ Akdeniz 1996, 233 vd. Havzanın bu kesiminde Şükrü Tül tarafından Lisans Tezi hazırlamak amacıyla bir çalışma yapılmıştur; S.Tül, Büyük Menderes Ovasında Prehistorik Yerleşimler, Ankara Üniversitesi, DTCF Lisans Tezi, 1981.

11 Gebel 1984, 29 vd.;Voigtlander 1983, 5 vd.; Gödecken 1988, 307 vd.; Schattner 1992, 369; Ayrıca Miletos kazı sonuçları için bkz: V. von Graeve, "Milet 1991", IstMıtt 42 (1992), 97 
doğal yollarla batıya uzanan ticaret ağının kilit noktalarından biri durumundaki Miletos, Büyük Menderes'in getirdiği alüvyonlar nedeniyle denizden kilometrelerce içeride kalmıștır. Miletos'un ve hemen güneyindeki Didyma'nın bilinen prehistorik tabakaları, havzadaki diğer kazı merkezlerine oranla çok kısıtlıdır. Buna karşın özellikle M.Ö. II. binyıl hakkında önemli bilgiler içermektedir. Miletos kazı ekibinin ve öteki Alman bilim adamlarının çevrede sürdürdükleri yüzey araşturmaları, hiç bilinmeyen Aşağı Menderes Havzası Prehistoryası'nın Ege Neolitik Çağı'na kadar uzandığını göstermiştir. Yine bir Alman araşturmacı olan Peschlow-Bindokat'ın Bafa Gölü çevresinde yürütttüğü çalışmalar da Bafa Gölü'nün prehistorik açıdan ilginç birikimlere sahip olduğunu belgelemiştir ${ }^{12}$.

Kazı ve araştırmalar sonucunda havzanın kültürel yapılanması belirginleşmeye başlamışsa da yayılımı tam olarak anlaşılamamışur. Bunun en büyük sebebi kazı ve yüzey araşurmalarının birbirini tamamlar nitelikte, yani ortaya çıkan tarihsel boşlukları ve problemleri çözecek şekilde planlanmaması, sadece sınırlı bir coğrafyanın durumunu yansıtması ve böylece çözümlenmesi gereken sorulara cevap verememesidir. Havzayı coğrafi olduğu kadar kültürel açıdan da bir bütün olarak değerlendirip sonuca ulaşmayı amaçlayan tek çalışma Marchese tarafından gerçekleştirilmiştir. Marchese'nin çalışmasında havzanın kapladığı coğrafyanın tümü olmasa da orta ve aşağı kesimlerinin erken dönemlerden Antik Çăglar'ın sonuna kadar uzanan kültürel yapılanması bir zincirin halkaları şeklinde, birbiriyle ilişkilendirilerek incelenmiştir. Ancak, Marchese'nin arazi çalışması yapmaması ve eserinde havzanın yukarı kesimlerine gerektiği ölçüde değinmemesi havzanın çeşitli dönemlerdeki kültürel bütünlüğünün ya da farklılığının algılanmasını engellemiştir ${ }^{13}$.

vd.; V. von Graeve, "1992 Milet Çalışmaları", XV. KST II, Ankara, 1994, 83 vd.; V. von Graeve, "1993 Yilı Milet Çalışmaları", XVI. KST I, Ankara, 1995, 405 vd.; V. von Graeve, "1994/95 Yılı Milet Calışmaları", XVIII. KST I, Ankara, 1997, 529 vd.

${ }_{12}$ Peschlow-Bindokat 19961 vd.; Peschlow-Bindokat, 1999, 461 vd. Peschlow tarafindan bu resimler hakkında değişik tarihlendirmeler yapılmış, hatta M.Ö. VIII. binyıla tarihlendirilmişlerdir. Resimler üzerinde yapılacak teknik analizler resimlerin tarihlendirilmesine yardımcı olabilir. Metinde de belirttiğimiz gibi bu çalışmamızda -daha erkene tarihlendirilebileceği ihtimalini de gõz ardı etmeden- resimleri şimdilik Geç Neolitik Çağ içerisinde değerlendirmeyi uygun bulduk. Peshlow'la yaptŭımız kişisel görüşmede ise bu resimlerin Erken Kalkolitik Çă̆'a ait olabileceği Peshlow tarafindan dile getirirmiştir. Verdiği bilgiler için kendisine teşekkür ederim.

${ }^{13}$ Marchese 1976,1 vd. 


\section{PREHISTORIK YERLEŞIM DOKUSU :}

Büyük Menderes Havzası'nda 129 merkezde prehistorik dönemlere ait kalıntılara rastlanmıştır. Yörenin prehistorik dönemdeki kültürel yapısına ışık tutacak merkez sayısının oldukça yüksek olmasına karşın, bunların coğrafi ve tarihsel dağılımında bir düzensizlik söz konusudur. Yerleşimlerin büyük çoğunluğu, özellikle Geç Kalkolitik Çağ'dan itibaren havzanın yukarı kesimlerinde yoğunlaşmaktadır. Yukarı Büyük Menderes Havzası'ndan uzaklaşıp ovaya inildikçe yerleşim sayısındaki azalma iyice belirginleşir. Araştırmalar sonucunda Yukarı Büyük Menderes Havzası'nda 76, Orta Büyük Menderes Havzası'nda 40, Aşağı Büyük Menderes Havzası'nda ise 13 prehistorik yerleşim ya da buluntu merkezi saptanmıştur. Ancak bu sayı, özellikle Yukarı Büyük Menderes Havzası'nda yeni bulunan merkezlerle her geçen gün artmaktadır $^{14}$.

Demir Çağ öncesindeki yerleşim sayısı coğrafi kesimler dışında tarihsel dönemlerde de değişim göstermektedir. En fazla yerleşimin belgelendiği evre Erken Tunç Çă̆ı II'dir. Bu dönemde 81 merkezde arkeolojik kalınt saptanmıştr. Bunlardan 4'ü Aşağı Büyük Menderes Havzası'nda, 18'i Orta Büyük Menderes Havzası'nda, 57'si ise Yukan Büyük Menderes Havzası'nda yer almaktadır. Erken Tunç Çă̆ı II'yi 56 merkezle Geç Tunç Çağı'nın ilk evresi izler. 56 merkezin 7'si Aşağı Büyük Menderes Havzası'nda; 16'sı Orta Büyük Menderes Havzası'nda; 33'ü Yukarı Büyük Menderes Havzası'ndadır. Sıralamada üçüncü sırada Orta Tunç Çağı vardır. Orta Tunç Çăğ'na ait kalıntıların 4'ü Aşağı Büyük Menderes Havzası'nda; 10'u Orta Büyük Menderes Havzası'nda; 28'i Yukarı Büyük Menderes Havzası'nda olmak üzere 42 merkezdedir. Erken Tunç Çağı III'de sayı yaklaşık olarak Orta Tunç Çağı ile aynıdır. Bu döneme ait kalıntılar 40 merkezde saptanmıştur. Bunlardan 4'ü

14 Burada belirttiğimiz 129 yerleşim tarafımızdan Ege Üniversitesi, Sosyal Bilimler Enstitüsü'ne bağlı olarak tamamlanan Büyük Menderes Havzası'nın Demir Çağı Öncesi Kültürleri, (İzmir, 1999) başhklı doktora tezindeki verilere dayanmaktadır. Bu sayı òzellikle Yukarı Büyük Menderes Havzası'nda henüz yayınlanmayan çok sayıda yerleşimle artmaktadır. Yukarı Büyük Menderes Havzası'nda, Çivril çivarındaki hōyükler hakkında verdiği bilgilerden òtürü arkeolog Hakan Kale'ye teşekkür ederim. Ayrica Müze Müdürlükleriyle Kültür ve Tabiat Varlıkları'nı Koruma Müdürlükleri tarafından yapılan çalışmalarla Denizli Acıpayam Gargın Hōyük, Corum Höyük, Pınarbaşı Hōyük, Bağardı Hōyük-Yuŏ Höyük, Kelerlik Höyük, Çivril Alan Hōyük, Çıkalı Hōyük, Gümüsssu Hōyük, Serinhisar Sarı Hōyük, Çardak Gölcük Höyüğü, Bozkurt Yenibağlar Hōyüğü, Sarayköy Kocahöyük, Merkez Baklan Höyük ve Kodare Hōyük'lerin varlı̆̆ı tespit edilmiştir. Bu hōyükler hakkında verdiği bilgilerden dolayı Prof.Dr. Abdullah Yaylah'ya teşekkür ederim. 
Aşağı Büyük Menderes Havzası'nda; 19'u Orta Büyük Menderes Havzası'nda; 17'si Yukarı Büyük Menderes Havzası'ndadır. Geç Tunç Çağı'nın II. evresindeki merkez sayısı 36'dır. Bu 36 merkezin 7'si Aşağı Büyük Menderes Havzası'nda; 15'i Orta Büyük Menderes Havzası'nda; 14'ü Yukarı Büyük Menderes Havzası'nda yer almaktadır. Yerleşim sayısı açısından Geç Tunç Çağı II. dönemini 30 merkezle Geç Kalkolitik Çağ izler. Bu döneme tarihlenen merkezler Aşağı Büyük Menderes Havzası'nda 3; Orta Büyük Menderes Havzası'nda 15 ve Yukarı Büyük Menderes Havzası'nda 12'dir. Erken Tunç Çağı I'deki merkez sayısı ise 26'dır. Bunlardan 5'i Aşağı Büyük Menderes Havzası'nda; 12'si Orta Büyük Menderes Havzası'nda; 9'u Yukarı Büyük Menderes Havzası'ndadır. Havzanın diğer dönemlerindeki merkez sayısı Erken Tunç Çağı II, Geç Tunç Çağı I, Orta Tunç Çağı, Geç Tunç Çağı II ve Erken Tunç Çağı I'e oranla oldukça düşüktür. Geç Neolitik Çağ'da Aşağı Menderes Havzası'nda 3; Orta Büyük Menderes Havzası'nda 5, Yukarı Büyük Menderes Havzası'nda 2 olmak üzere toplam on merkez saptanmıştur. Havzada buluntu merkezi sayısının en az olduğu dönem Erken-Orta Kalkolitik Çağlar'a aittir. Erken-Orta Kalkolitik Çağ'da 4 merkez (Aşağı Büyük Menderes Havzası'nda 3, Yukarı Büyük Menderes Havzası'nda 1) saptanmıştur.

Yukarıda, havzanın Demir Çağ öncesindeki yerleşimleri sayısal üstünlüğe dayalı olarak incelenmiştir. Çalışmamızın bundan sonraki kısmında bu yerleşimler ve dolayısıyla kültürel özellikler tarihsel bir sırayla ele alınacaktır.

Havzada üzerinde bazı kuşkular devam etmesine karşın şu an için en erkene tarihlenebilecek kalınular Beşparmak Dağları'ndaki kaya sığınaklarındaki resimlerdir. Beşparmak resimlerine ilaveten, çakmaktaşı buluntuları ile dikkat çeken Çine-Kızıltaş, Neolitik Çă̆'dan da önceye inebilecek merkezler olabilir $^{15}$. Bu merkezlerdeki kültürel yapılanmanın daha iyi yorumlanabilmesi için sistemli araşurmalara ihtiyaç vardır. Beşparmak resimlerinin kesin tarihlemesi bile henüz yapılamamıs, çeşitli tarihleme önerileri getirilmiştir ${ }^{16}$.

15 Akdeniz 1996, 240, 241; Peschlow-Bindokat 1996, 17 vd.; 1999463 vd. Kızıltaş'ta yüzeyde dikkat çeken çok miktardaki çakmaktaşı parçalarının gerçekten prehistorik çağlara ait olduğunun saptanması için konunun uzmanı bilim adamları tarafından ayrıntılı çalışmalara ihtiyaç vardır. Bilindiği gibi Anadolu'nun bazı yörelerinde modern zamanlarda kullanılan dòven bıçaklarının prehistorik çakmaktaşlarıyla karıştrıldığı da olmuştur.

${ }^{16} \mathrm{C}$. Gerber, Beşparmak yöresinde duvarları resim içermeyen, ancak zemininde çanak çömlek parçalarının bulunduğu yeni bir mağaradan sōz etmektedir. Henūz yayımlanmayan bu parçalar Neolitik Çağ'ın geç evrelerine ait olmalıdır. Verdiği bilgiler için C. Gerber'e teşekkür ederim. 
Bu çalışmamızda, Beşparmak kaya sığınakları da daha erkene indirme ihtimalini de göz önüne almakla birlikte şimdilik ihtiyatla yaklaşılarak Geç Neolitik Çağ merkezleri arasında gösterilmiştir. Beşparmak da dahil olmak üzere Geç Neolitik Çağ'daki 10 merkez havzanın aşağı ve orta kesimlerinde yoğunlaşmaktadır. Bunlardan bir kısmı Didim-Miletos çevresinde, deniz kıyısında ya da yakınında yer almaktadır. Bu döneme ait buluntular içeren kazı sadece Aphrodisias'da gerçekleştirilmiştir ${ }^{17}$. Kazılan alan 5 m.'ye yakın bir deposit olmasına karşın yeterince bilgi edinilememiştir. Aphrodisias bu dönemden sonra bir süre terk edilmiştir. Bunun sebebi bilinmemekle birlikte Joukowsky de dahil olmak üzere bazı araşurmacılar tarafından kuzeybatıdan yapılan göçlerle açıklanmaya çalışılmıştır ${ }^{18}$. Fakat sonraki dönemlere ait buluntular da kuzeybatı kültürünün etkisini yansıtacak veriler yoktur. Bu nedenle yerleşimdeki boşluğu doğal faktörlere bağlamak şu an için en tutarlı görüş olacakur.

Erken ve Orta Kalkolitik Çă̆'a ${ }^{19}$ ait buluntular içeren dört merkez saptanmış ve bunlar da Aşağı Büyük Menderes'deki yerleşimlerdir. Bunlarda Erken Kalkolitik Çăg'a dair bir kuşku olmamakla birlikte Orta Kakolitik Çağ'da kesin olarak yerleşimin olup olmadiğı kuşkuludur. Orta Kalkolitik Çağ varlığı halen tartışma konusu olan bir süreçtir. Ancak Büyük Menderes Havzası'nın yakınındaki Kuruçay Höyüğü'nün 6A-4 tabakaları arasında ele geçen çanak çömlek buluntuları, Anadolu'nun diğer bazı yöreleri için kabul edilen Orta Kalkolitik Çağ kavramının Büyük Menderes Havzası'ndaki bazı kronolojik boşlukları doldurabileceğini ortaya koymaktadır ${ }^{20}$. Böylece, Elmalı yöresi, Eskişehir-Kütahya çevresi, Orta Anadolu'nun güneyi, Trakya ve Güneydoğu Anadolu için kullanılan Orta Kalkolitik dönemini havza için de uygulayabiliriz. Orta Kalkolitik kabul edildiği taktirde tüm Güneybatı'nın olduğu gibi havzanın da Geç Kalkolitik ve öncesi tabakalarının tarihleri yeni-

${ }^{17}$ Joukowsky $1987,32 \mathrm{vd}$.

${ }^{18}$ Joukowsky 1986a, 166.

19 Erken Kalkolitik Çağ'dan sonra gelen evre uzun yıllar boyunca Geç Kalkolitik adıyla anılmışur. Ancak son zamanlarda Erken ile Geç Kalkolitik arasında Orta Kalkolitik olarak adlandırılan bir evrenin varlığı kabul edilmektedir. Batı ve Orta Anadolu genelinde düşünüldüğünde bu evrede yalnızca çanak çōmlek özelliklerinde değil aynı zamanda sınırlı olmakla birlikte yerleşimlerin boyut ve tiplerinde de bir değişimin yaşandığı anlaşılmaktadır. C.Eslick, "Middle Chalcolithic Pottery from Southwestern Anatolia", AJA 84 (1980), 5 vd.; M. Mellink, "Anatolian Chronology", Chronologies in Old World Archaeology, Vol. I, (Ed. R.W.Ehrich), Chicago/Londra, 1992, 207 vd., Tablo 2.

${ }^{20}$ Yakar, 1985, 108; R.Duru, Kuruçay Höyük II, Ankara, 1996, 101, 101, 
den gözden geçirilmeli, özellikle Geç Kalkolitik Çă̆'ın tarihi daraltularak bir bölümü Orta Kalkolitik içerisinde değerlendirilmelidir. Beycesultan kazıcıların tarafından önerilen ve üzerindeki soru işaretlerinin halen kaybolmadığı Geç Kalkolitik için verilen 2000 yıllık zaman dilimi de böylelikle daraltılmış olunacaktur ${ }^{21}$.

Geç Kalkolitik Çağ'da tüm Batı Anadolu'da olduğu gibi havzada da yerleşim sayısı artarak 30'a ulaşır. Bu dönemden itibaren havza kültürü kendine özgü özellikler sergilemeye başlar. Geç Kalkolitik yerleşimlerin en ünlüsü hiç süphesiz Beycesultan'dır. Beycesultan bu dönemde yalnız Güneybatı Anadolu'nun değil tüm Bat Anadolu ve Ege Havzası'nın başlıca yerleşimlerinden biridir. Beycesultan'da Geç Kalkolitik yerleşimin son derece küçük bir bölümü kazılmış olmasına karşın ele geçen buluntular "Beycesultan Geç Kalkolitik Kültürü" olarak adlandırılan bir kültürle karşı karşıya olduğumuzu göstermektedir. Bu kültürün en iyi gözlemlendiği maddi buluntular çanak çömleklerdir. Beycesultan dışında Kusura ve Aphrodisias kazılarında ve yüzey araşurmalarında oldukça geniş bir sahada bulunan bu çanak çömleğin başlıca özelliği formlarının yanında siyah zemin üzerine beyaz boya bezemesidir. Güneybat Anadolu dışında Akhisar-Manisa yöresi başta olmak üzere Kuzeybatı Anadolu, bazı Ege Adaları da bu türde çanak çömleğin ele geçtiği merkezlerdir ${ }^{22}$. Beycesultan Geç Kalkolitik Kültürü çanak çömleğin yanısıra metal işçiliğinde de kendinden söz ettirir. Beycesultan'ın XXXIV. tabakasının metal buluntuları bir kavanoz içerisine konulan iğne, keski, biz, tuğ ve

${ }^{21}$ Lloyd-Mellaart 1962, 18 vd., Fig. 3. Beycesultan'da Geç Kalkolitik tabakalar XL-XX arasına aittir. Bu tabakalar kūçük höyüğŭn güneybatı kōşesinde yer alan SX sondajında saptanmışur. Ancak XL. tabakada arkeolojik herhangi bir buluntu ele geçmemiştir. Beycesultan kazıcıları Geç Kalkolitik için her 20 tabakaya yaklaşı 100 'er yllık tarihler vererek neredeyse 2000 yllık kabul edilmesi zor bir tarih ōnermektedir. Mellaart'ın görüşūnün temelinde Hacılar kültürünün hemen ardından Beycesultan kültürünü başlatmak, dolayısıyla kültürel bir devamlılık prensibi yatmaktadır. Beycesultan'dan alınan az sayıdaki C14 tarihlemesi de Mellaart'ın görüşünü desteklemememektedir. Mellaart Beycesultan'ın Geç Kalkolitik tabakalarını "...uzun süre yaşanmış ancak gelişmesi yavaş" bir evre olarak nitelemekteyse de bu tarihlemenin en azından bir kısmının Orta Kalkolitik Çă̆ içerisinde yer alması gerekmektedir.

${ }^{22}$ A.Furness, "Some Early Pottery of Samos, Kalimnos and Chios", PPS 22 (1956), Fig.8:4, 9:7, 6; Lloyd-Mellaart 1962, 106.; D.French, "Early Pottery Sites from Western Anatolia", Bulletin of the Institute of Archaeology 5 (1965), 15 vd.; D.French, "Prehistoric Sites in Northwest Anatolia II, The Balıkesir-Akhisar-Manisa Areas", AS 29 (1969), 59; J.D.Evans-C.Renfrew, Excavations at Saliagos near Antiparos, Oxford, 1968, Fig. 31.2, 32.1, 33.5-7, 57.11,19, 39.6, 40.14-19, 42, 43, 45.1-5. 
bıçak ağızlarından oluşmaktadır ${ }^{23}$. On bakır parçadan düşük oranda arsenik içeren ikisi, arsenik katkılı bakırın bu dönemden itibaren havzada üretildiğini kanıtlamaktadır. Beycesultan ile hemen hemen çağdaş bir yerleşimin belgelendiği Pekmeztepe Açma 2, tabaka VIIIa'da metal buluntular ele geçmiştir ${ }^{24}$. Kuruçay'ın Geç Kalkolitik Çağ 6A tabakası metal buluntularıyla birlikte ${ }^{25}$ Bat Anadolu'daki en eski metal eser gruplarından birisini oluşturan bu örneklerin Büyük Menderes Havzası'nda bulunması hiç şüphesiz havzanın belirginleşmeye başlayan kültürel yapısından ve zengin maden rezervinden kaynaklanmaktadır ${ }^{26}$. Geç Kalkolitik Çağ'ın son evresinde Beycesultan'da Megaron planlı yapılar ortaya çıkar. Bu yapılar Anadolu'da bilinen en erken megaron örnekleridir ${ }^{27}$. Geç Kalkolitik Çağ'a ait tabakaların saptandığı diğer bir merkez Kusura A'dır. Ayrıca son kazı raporlarında Miletos'da Geç Kalkolitik Çă̆'a kadar inildiği bildirmekteyse de Kusura gibi Miletos'un da bu dönem tabakalan tartışılabilir ${ }^{28}$. Kusura ve Aphrodisias'ın çanak çömlek buluntuları ise yerleşimlerin kendine özgü bir kültür oluşturduğunu ispat edecek yoğunlukta değildir. Genel olarak bu yerleşimlerin Beycesultan Geç Kalkolitik kültürünün etkisinde kaldığı söylenebilir. Kusura'nın A mezarlığı çanak çömlek buluntuları da Göller Bölgesi'yle bir etkileşimi belgeler.

Elimizdeki kanıtlara göre Büyük Menderes Havzası Erken Tunç Çă̆ı I Kültürü'nün yerel Geç Kalkolitik Çağ, özellikle de Geç Kalkolitik Çağ IV Kültürü'nden türediği söylenebilir. Erken Tunç Çağı I'e kültürel bir kesinti olmaksızın ulaşılmışur. Ne Beycesultan ne de Aphrodisias'da böyle bir kesintiden söz edilmez. Bu durum çanak çömlekde kolaylıkla gözlenmektedir.

23 Lloyd-Mellaart 1962, 280-283, Pl.11, Fig.F.8; P. de. Jesus, The Development of Prehistoric Mining and Metallurgy in Anatolia, BAR International Series 74 (i,ii), Oxford, 1980, 76; J.Yakar, "Regional and Local Schools of Metalwork in Early Bronze Age Anatolia, Part I", AS 34 (1984), 64.

${ }^{24}$ Buluntular Pekmeztepe Açma 2, tabaka VIIA, VIID, VIIC ve VII'de ele geçmiştir. Joukowsky 1986a, 288, Fig.274; Joukowsky 1986b, 379.36, 385.49, 394.27, 400.21, 400.22, 400.15.

${ }^{25}$ Duru 2000, 58.

${ }^{26}$ G.Budanur, MTA Enstitüsünce Bilinen Türkiye Yeralu Kaynakları Envanteri, Ankara, 1977, 19, 20, 45, 46, 108, 169, 170; MTA verilerine göre havzadaki demir yatakları: Aydın Bozdoğan-Altuntaş, Genzile, Çine-Akçaova Bucağı, Karpuzlu Bucağı-Ömerler Köyü, Mutaflar Köyü, Çatak Köyü, Karacasu-Seki Kōyü, Yazır Köyü, Eymir Kōyū, Germencik-Çamkōy, NazilliGireniz Köyū, Söke-Kızılıșık Kōyü, Bağarası Bucağı-Cavdar Kỏyü, Denizli Karcı Köyū, Manastur, Tavas-Uzunpınar Köyū, bakur yatakları: Aydın Söke-Yaylakōy, Denizli Çal Bakla Kōyū, Selçekli Köyü, Çivril Koçak, Saraykōy Kıranyeri, Tavas Kızılcabölük, gūmūş yatałłarı: Denizli Işıklı ve çevresinde bulunmaktadır.

27 Naumann 1975, 357.

${ }^{28}$ V. von Graeve, "1996/1997 Yulı Milet Çalışmaları”, XX. KST I, Ankara, 1999, 584. 
Beycesultan'ın XX/XIX tabakalarının çanak çömleği, Geç Kalkolitik Çă̆' dan Erken Tunç Çağı I'e geçişi yansıtmaktadır. Bu nedenle, Beycesultan'ın XX/XIX. tabakaları Geç Kalkolitik Çağ Kültürü'nden Erken Tunç Çağı I Kültürü'ne geçiş olarak değerlendirilmelidir. Havzanın Erken Tunç Çağı I kültürü, havza dışında Güneybau Anadolu'da geniş bir alana yayılmışur. Ancak, bu yayılım önceki Geç Kalkolitik Çağ ve sonraki Erken Tunç Çağı II'ye oranla sınırlıdır. Büyük Menderes Havzası Erken Tunç Çağı I Kültürü'nün etkisi Marmara Denizi'nin güneyi, Eşkişehir-Kütahya yöresi, yoğun bir biçimde Afyon yöresi, Gavurtepe başta olmak üzere Akhisar-Manisa yöresi, Elmalı yöresi ve Göller Bölgesi'ne uzanmışur. Ege Adaları'nda Geç Kalkolitik Căğ'daki yoğun Beycesultan etkisi bu evrede azalır ${ }^{29}$.

Yukarıda da belirtildiği gibi Erken Tunç Çağı I Kültürü havzanın Geç Kalkolitik Çağ Kültürü'nden türemiştir. Bu dönemde yerleşilen höyük sayısında Geç Kalkolitik Çắ'a oranla küçük bir azalma olmasına karşın, maddi kültür eserlerinde belirgin bir kalite artışı gözlenir. Böylece, arkeolojide kültürün gelişiminin yerleşim sayısının artmasıyla doğru orantılı olduğu yönündeki görüş, Beycesultan Erken Tunç Cağı I ve Geç Kalkolitik Çağ örneklerinin karşılaştırılmasıyla çürütülmüş olur. Her dönemde olduğu gibi Erken Tunç Çağı'nda da kültürel gelişimin ekonomik gelişim tarafından desteklenmiş olması gerekmektedir. Kazı sonuçlarından anlaşıldığı kadarıyla havzada bu gereklilik yeterince sağlanmışur. İlk kez bu dönemde çok çeşitli et tüketilmeye başlanır. Geç Kalkolitik Çă̆'da koyun-keçi eti tüketilmekteyken Erken Tunç Çağı I'de koyun-keçi dışında, geyik, domuz ve sığır eti temel protein maddesi olmuştur. Metal teknolojisindeki gelişme bu zincirin en son halkasını oluşturmaktadır. Özellikle Kusura gerek alet sayısı, gerekse çeşitliliği açısından ayrı bir kültür olarak nitelenebilecek boyuttadır. Dönemin başlıca madeni bakırdır. Bakır, -gerçek anlamda- ilk olarak Geç Kalkolitik Çağ'da kullanılmaya başlansa da Erken Tunç Çağı I'de bakırdan araç gereç yapma teknikleri gelişmiş ve bakıra arsenik katularak son derece kaliteli eserler üretilmiştir. Bakırın ısıtıldığı zaman ıslatılmış kil gibi kolayca şekillendirilebilmesi ve soğuyunca taş kadar sert olması tercih edilme sebepleridir. Dönemin bir başka özelliği bakıra 1/6 oranında kalay karıştırılarak "tunç" adı

${ }^{29}$ T.Efe, "Patterned Reserve-Slip Decoration in the Early Bronze Age of Western Anatolia", Anatolica 13 (1986), 2; T.Efe-A.Topbaş-A.Ilash, "Salvage Excavations of the Afyon Archaeological Museum, Part I:Kaklık Mevkii, A Site Transitional to the Early Bronze Age". Studia Troica 5 (1995), 3373; S.W.Manning. The Absolute Chronology of the Aegean Early Bronze Age, Sheffield, 1995, 74. 
verilen dayanıklı bir alaşımın üretilmesidir. Arsenik yerine kalayın bakıra katkı maddesi olarak katılmaya başlanması, bilerek ya da bilmeyerek insan sağlığı üzerindeki olumsuz etkileri de kaldırmıştur. Görüldüğü gibi bakır, bu dönem kültürlerinde çok önemli bir role sahiptir. Havzada birçok yerde bakır madeni yataklarının varlığı bilinmektedir. Ancak bu yataklar daha çok ulaşılması tehlikeli sarp dağlarda yer almaktadır. Bu nedenle, bakırı yataktan çıkaran, yerleşimlere ulaşuran, eritip bileşenlerinden ayıran, belki de ihraç eden ve son olarak da işleyen bir iş düzeni kurulmuş olmalıdır. Bu süreç ancak koordineli bir iş bölümüyle aşılabilir. Prehistorik Çağlarda bakırı eritmek için kullanılan tek nesne yaş ağaçlardan elde edilen maden kömürüdür. Bu nedenle havzada metalurjinin hızlı gelişme sürecine girmesinin yöredeki zengin ormanlık alanlarda kademeli bir azalmaya yol açması muhtemeldir.

Beycesultan'da Geç Kalkolitik Çăg'da ortaya çıkan megaron tarzındaki yapılar Erken Tunç Çağı I'de de devam eder. Bu dönemde yerleşim bir sur duvarı ile çevrilmiştir. Taş temel üzerine kerpiç kullanılarak inşa edilen bu duvar, bölgedeki karışıklıkların bir göstergesidir. Beycesultan tabaka XIX ile birlikte mimaride büyük değişimler başlar ${ }^{30}$. Yapı malzemesi olarak taş kullanılmıştır. Geç dönemlere doğru taşın kullanımı artar. Erken Tunç Çağı I, özel kapalı mekanlarda dini merasimlerin yapılmaya başlandığı bir evredir. Adeta bir şehir görüntüsü kazanan Beycesultan tabaka XVII'deki megaron tarzındaki yapı, plan ve içerik açısından bir kutsal alan ya da tapınak olarak değerlendirilebilir ${ }^{31}$. Planı evlerden farklı olmayan yapının ön odasının orta kesiminde kil bir yükselti yer alır. Bu yükselti, komposit bir sunakdır. Sıvalı kilden yapılan sunak, ikiz stelden oluşmaktadır. İkiz stel, çifte tanrı düşüncesinin somutlaşurılmıs şeklidir ${ }^{32}$. Steller arasında sıvı adakları için bir çukurluk, önde ise hayvanların kurban edildiği kilden yapılmış bir çift kutsal boy-

${ }^{30}$ Lloyd-Mellaart 1962, 27.

${ }^{31}$ K.Werner, The Megaron During the Aegean and Anatolian Bronze Age, Studies in Mediterranean Archaeology, vol. CVIII, Jonsered, 1993, 22, 23.

32 Anadolu'da stel geleneği pekçok yerleşimden bilinmektedir. Erken Tunç Căğı'nın erken evrelerine tarihlenebilecek Orta Troia I'deki insan yüzlü kabartmalı stel ve Prof.Dr. Ersin Doğer tarafından Helvacıkōy-Hōyücek'de bulunmuş kazıma figürlü stel dışında Troia tabaka IV oda 402 ve tabaka V ev 501'de stel benzeri dikmeler saptanmışur. Ayrıca tabaka Vla'daki anteli evin ve tabaka VII'deki kulenin önünde dört adet geniş taş sūtun bulunmuştur. Troia dışında Konya Karahöyük, Alişar, Kültepe, Alacahöyük, Horoztepe, Pulur, Kuruçay ve Tarsus'da değişik òzelliklere sahip steller bulunmuştur. Blegen ve diğerleri 1951, 144, 258; Yakar 1974, 151; E.Doğer, "Helvacıkōy-Hōyücek'de Bulunmuş Kazıma Figürlü bir Stel", Ege Üniversitesi Arkeoloji Dergisi III, 1995, 61 vd. Prof. Dr. Ersin Doğer'e verdiği bilgiler için teşekkür ederim. 
nuz bulunmaktadır. Beycesultan XVII. tabaka megaronunun en önemli özelliği ilk dini yapılardan biri olmasıdır ${ }^{33}$. Yapının ölçüleri bir grubun toplu olarak ibadet yapmasını sağlayacak ölçülerdedir. Böylece, Geç Kalkolitik Çă̆' da evlerde ya da açık havada sürdürülen dinsel aktivitelerin, bu dönemden itibaren özel mekanlara kaydırıldığı ve bir düzenleme yapıldığı anlaşılmaktadır. Ayrıca toplumda dinsel törenlerden sorumlu bir sınıf oluşmuştur. Ancak bu sınıfa dahil olan insanların, yani rahiplerin yönetim ile bağlantısı bilinmemektedir. Buna karşın sunak odasının gerisindeki odaya rahip odası adı verilmiştir. Önceki dönemlerdeki gerçekçi idollerin aksine Erken Tunç Çağı'nda tümüyle soyutlaşmış özellikteki mermer idoller üretilmeye başlanır ${ }^{34}$. Bu yapıdaki rahip odasının içinde çok sayıda keman (violin) formlu idol, metal eşyalar, çeşitli kaplar ve dağ kristaliyle mermerden yapılmış havan ile dibek ele geçmiştir. Beycesultan ve Kusura'da ele geçen, ana tanrıçayı ifade ettiği anlaşılan bu idoller ve ortaya çıkarılan kutsal alanlar, havza toplumlarında dini inançların yeniden şekillenmeye başladığı görüşünü desteklemektedir. Ölü gömme gelenekleri hakkındaki bilgiler de dini inanışların anlaşılmasında yardımcı olabilir. Kusura kazılarında B evresine tarihlenen değişik mezar tiplerine rastlanmışur ${ }^{35}$. Bu mezarlar, hocker pozisyonunda cesedin yerleştirildiği küp mezarlar, gömünün yapılmadığı küp mezarlar, taş sanduka mezarlar ve toprak mezarlardan oluşmaktadır. İskelet başının ve küp ağzının batıya çevrildiği Kusura küp mezarları bu özellikleriyle Batı Anadolu'daki diğer küp mezarlardan ayrılmaktadırlar. Babaköy, Yortan ve Karataş mezarlarında küplerin ağız kesimleri ve iskeletlerin başları daima doğuya dönüktür. Güneşin doğuşu esnasında güneş ışınlarının üzerine yansıması ve böylece bir tür yeniden doğuşun gerçekleşmesi için küplerin ağızlarının ve dolayısıyla iskeletlerin başlarının doğuya çevrilmesi düşüncesi oldukça tutarlı bir yorumdur. Ancak, Kusura mezarlarında olduğu gibi küplerin ağızlarının batıya, güneşin battığı yöne çevrilmesinin yeniden doğuşla hiçbir ilgisi yoktur. Mezarlanın tümünün aynı yöne çevrili olması da rastlantı

33 Gavurtepe'de kazı kapatulmadan önce sürdürülen son kazılarda da Beycesultan'da ortaya çıkarılan dini yapı ile çă̆daş bir kutsal alan bulunmuştur. Gavurtepe kutsal alanı Beycesultan'daki oornekle aynı plana sahip olmasına karşın Beycesultan'daki sunağa burada rastlanmaz. Gavurtepe'deki kutsal alanın avlusunda koyun-keçi tứrūne ait hayvan kemikleri ve geyik boynuzlarının ele geçmesi kazı başkanının da belirttiği gibi hayvan kurban edildiğini akla getirmektedir. R.Meriç, "1992 Yılı Alaşehir Kazı Raporu”, XV. KST II, Ankara 1995, 422 vd.

${ }^{34}$ Lamb 1937, 28, 29,50, Fig. 11:5; Lamb 1938, 251, 266, Fig. 17:1-4; Lloyd-Mellaart 1962. Fig.F.1-12.

${ }^{35}$ Lamb 1937, 55 vd., Fig.25, PI.25:1 
ihtimalini ortadan kaldırmaktadır. Dolayısıyla, Batı Anadolu küp mezarları içerisinde farklı yöne çevrili tek küp mezarlık olan Kusura B mezarlarının, değişik bir dini inanışla ilgisi olabilir. Kusura'ya çok yakın çoğrafyada yer alan Beycesultan'da ise bu döneme tarihlenecek mezarlık bulunamamıştur. Beycesultan'da Geç Kalkolitik Çağ'da başlayan ve küçük çocukların intra mural şekilde çömlekler içerisine konmasından oluşan gömü tarzı Erken Tunç Çağı I'de de devam eder. Ancak, bu mezar şekli sadece çocuklara özgü olduğundan yetişkinlerin gömüldüğü ayrı bir mezarlık olmalıdır.

Erken Tunç Çağı I'de üretilen pişmiş toprak kaplar kaliteli eserlerdir. Formlar arasında çanaklar, küçük testi ve kavanozlar başlıcalarıdır ${ }^{36}$. En çok kırmızı ve parlak astar kullanılmışır. Kap formlan genelde Geç Kalkolitik Çağ örneklerine benzemesine karşın balık pulu motifi ve barbotin tekniği ilk kez bu dönemde ortaya çıkar.

Erken Tunç Çağı II'ye gelindiğinde havzanın kültürel yapılanmasında önemli değişimler gözlenir. Büyük Menderes Havzası Erken Tunç Çağı II kültürünün Kuzeybatı Anadolu Erken Tunç Çağı I kültüründen etkilendiği kesinlik kazanmış bir teoridir. Yaptığımız yüzey araştırmalarında da bu teoriyi destekleyecek veriler saplanmıştır. Troia I'in yıkılışını izleyen süreçte kuzeybatıdaki bazı yerleşimler terk edilmiş ve burada yaşayan toplumlar güneye-güneydoğuya doğru yayılmışlardır. Bu yayılım alanı içerisinde Güneybatı Anadolu'nun ve özellikle Büyük Menderes Havzası'nın da bulunduğu anlaşılmaktadır. Böylece, Kuzeybatı Anadolu Erken Tunç Çağı I Kültürü, havzaya Erken Tunç Çağı II'de ulaşmış ve yerli kültürle birleşerek sentez yapıda yeni bir kültür oluşmasına neden olmuştur. Bu sentez kültür içerisinde Beycesultan'ın yanı sıra Kusura da kendine özgü eserler meydana getiren önemli bir kültür durumuna erişir. İki kültürün yayılım sahaları birbirleriyle çakışmakta, özellikle Beycesultan'ın etkisi çok geniş bir coğrafyada hissedilmektedir. Erken Tunç Çă̆ı II Beycesultan Kültürü, kuzeyde Afyon yöresi, kuzeybatuda Uşak, güneybatıda Göller Bölgesi, sınırlı olarak Elmalı yöresi ve Eskişehir yöresine kadar yayılmıştı ${ }^{37}$. Bu kültürün batıdaki en uç noktası Samos Adasıdır. Adadaki Heraion II ve Tigani yerleşimleri, Beycesultan tabaka XIIIa'nın çanak çömlek özelliklerini sergilemektedir. Kusura Kültürü ise daha sınırlı bir yayılım alanını kapsar. Beycesultan'ın aksine bu kültür

${ }^{36}$ Yakar 1985, 163.

${ }^{37}$ Lloyd-Mellaart 1962, 181; French 1968, 36, 38; C.Renfrew, Emergency of Civilization : The Cyclades and the Aegean in the Third Millenium B.C., Londra, 1974, Fig.20/1,2,3,4. 
kuzey ve kuzeybatıda görülmez. Kusura Kültürü'nün Yukarı Büyük Menderes Havzası'ndan Isparta yöresine kadar uzanan alanda etkisi belgelenmiştir. Beycesultan ve Kusura Kültürü'nün yaylım sahaları, Erken Tunç Çağı I'de azalan bölgesel ilişkilerin Erken Tunç Çağı II'de yeniden artmaya başladığını göstermektedir.

Erken Tunç Çağı II'de yerleşim sayısında büyük bir artş̧ meydana gelir. Havzada tüm prehistorik çağlar boyunca en fazla yerleşim bu döneme aittir. Aşağı Büyük Menderes'de 6, Orta Büyük Menderes'de 18, Yukarı Büyük Menderes'de 57 olmak üzere 81 yerleşimde iskan saptanmıştur. Erken Tunç Çağı II'de özellikle Yukarı Büyük Menderes'deki yerleşim sayısının artışı dikkat çekicidir. Bu artıs, Kuzeybatı Anadolu'dan gelen göçlerin rotasının Yukarı Büyük Menderes'den geçtiğini ve göçmenlerden en azından bir kısmının daha çok Yukarı Menderes Havzası'nı yurt olarak şeçtiklerini akla getirmektedir. Orta Büyük Menderes'deki Dandalas Vadisi'nde yer alan Aphrodisias'da bu dönemde önemli bir değişim gerçekleşmiş, Pekmeztepe bilinmeyen bir sebeple terk edilmiş ve yerleşim Akropolis'e taşınmışur.

Kuzeybat Anadolu'dan gelen ve sentez bir kültür oluşumuna neden olan bu göçleri en iyi anlatan buluntular çanak çömleklerdir. Havzada çark yapımı ve pembe astarlı mallar ilk kez bu dönemde kullanılmaya başlanmışur. Ancak, elde üretilmeye devam edilen pek çok form vardır. El yapımı kapların kalitesi çarkda yapılanlara oranla daha yüksektir. Bu dönemde çift kulplu içki kapları (depaslar), tankart türü kaplar, gaga ağızlı kaplar, içe dönük ağız kenarlı kaideli çanaklar, içe çekik ağız kenarlı makara kulplu çanaklar ve değişik bezeme şekilleri (beyaz boya, kazıma bezeme) ortaya çıkar. Bu eserler Beycesultan, Aphrodisias ve Kusura kazılarında Erken Tunç Çă̆ı II, Troia'da ise Troia I sonu ve II. tabakada bulunmuştur. Havzada bu dönemde Troia dışında Yortan türü mallar da görülmeye başlanır. Özellikle Beycesultan tabaka XV, XIV, XIII ve Aphrodisias buluntuları Yortan'in A sınifi mallarına benzer ${ }^{38}$. Bu dönemde yöresel bir kültür haline gelen Kusura oldukça önemli bir çanak çömlek üretim merkezidir ${ }^{39}$. Kendi adıyla anılan ve metalik formları taklidden türediği anlaşılan kaplar, havzanın en güçlü yerleşimi Beycesultan'da da bulunmuştur. Bu kapların formlarının metal örneklerin

${ }^{38}$ Lloyd-Mellaart 1962, 181, Fig.P.41; T.Kamil, Yortan Cemetery in the Early Bronze Age of Western Anatolia, BAR

International Series 145, Oxford, 1982, 64, 76.

${ }^{39}$ Lamb 1937, pl.XXXIII, no.6 ve 7.; French 1968, 35. 
kopyası olduğu kabul edilirse Kusura'da gelişmiş bir metal okulundan söz etmek gerekecektir. Ancak kazılarda ele geçen metal eserler bu düşünceyi destekleyecek verilerden yoksundur. Kazılarda bakır eserlerin yanı sıra tunçdan yapılma süs eşyaları, aletler ve silahlar da bulunmuştur. Bu dönemin Kusura için bir başka özelliği kendi adıyla anılan idol tipinin ortaya çıkmış olmasidir ${ }^{40}$.

Beycesultan Erken Tunç Çağı II tabakaları dönemin mimari özellikleri hakkında önemli bilgiler içermektedir. Bu dönemin ilk yerleşimini oluşturan tabaka XVI'da hem sivil hem de dini mimariye yönelik kalıntular saptanmış$\operatorname{tur}^{41}$. Bu tapınaklar yıkıldıktan sonra yeni tapınağın da aynı yere inşa edilmesi özellikle Mezopotamya kültürlerinde bilinen bir uygulamadır. Daha önceki ev sunaklarından türeyen çifte tapınaklar Beycesultan'daki mimari gelişimi açıkça belgelemektedir. Bu tapınaklara, önceki kutsal alanlar gibi batudan girilmektedir. Çifte tapınaklar, herbiri sunak odası ve bu odanın gerisinde yer alan rahip odasından meydana gelen iki ayrı bölümden oluşmuş iki yapıdır. Sunak odasının ortasında iki stel, stele yakın noktalarda da bir ağaç direk yer alır. Bu direk, Minos'da ya da geç dönemlerdeki Arap kabilelerinde olduğu gibi başlı başına bir kült olarak değerlendirilebilir. Bazı durumlarda stelin önünde kil boynuz ve kaldırım bulunur. Boynuz, Anadolu'da Çatalhöyük'ün Neolitik tabakalarından itibaren süregelen boğanın kutsallığının bir uzantısıdır. Bu boynuzlara kurban edilecek hayvanın boynu konulmaktadır. Ayrıca kanın akıtılması için yapılmış bir kan sunağı da (havuz) vardır. Kan sunakları Orta Tunç Çağı'nda Minos'da da kullanılacakur. Diğer Beycesultan tapınaklarında olduğu gibi bu tapınaklar da tahıl siloları tahıl adağını düşündürmektedir. XV. tabakadaki tapınak Beycesultan tapınaklarının en tipik olanıdır. Tapınak tabanında yanmıs hasır kalıntıları ve ayrıca sağdaki A odasındaki sunağın arkasında hasır örtünün (perde?) asılı olduğu anlaşılmaktadır. Beycesultan'da XIV. tabakadan itibaren ikiz tapınakların arasına değişik amaçlı odaların yapılmasıyla dikkat çeker. Bir önceki tabakadan kesin olarak varlığı bilinen stellerin arkasındaki hasırın (perde?) varlığına dair veriler vardır. XIII. tabaka, tapınakların dini özelliklerini kaybetmeye başlayarak sivil yapılar haline geldikleri dönemdir. Havzanın Erken Tunç Cağı II dönemi mimarlığı hakkında bilgi veren bir başka yerleşim Kusuradır. Kusura'nın B3 tabakasında bir yolun iki yanına dizilmiş durumda ev

\footnotetext{
${ }^{40}$ Lamb 1938, Pl.84.II.

${ }^{41}$ Lloyd-Mellaart 1962, 36 vd.; Yakar 1974, Fig.1.
} 
kalıntuları saptanmıştur. Yerleşimi ikiye ayıran yolun bat kesiminde "külliye" olarak nitelendirilebilecek bir yapı kompleksi vardır ${ }^{42}$. Bu kompleksde yer alan evler, aralarında bağlant kapıları olmayan bir bütünü oluşturur. Beycesultan'da olduğu gibi bu evierde de megaron plan uygulanmıştur. Dönemin sonlarına doğru Kusura'da, Beycesultan sunaklarına benzer sunak ve kutsal alan inşa edilmiştir. Dolayısıyla, özellikle Yukarı Büyük Menderes'in dini mimari açısından ve belki de dini inanışlar açısından ortak özellikleri paylaştŭ̆ düşünülebilir. Kutsal alanlar ve sunaklar dışında dönemin dini yaşantısının anlaşılmasını sağlayan bir başka arkeolojik kanıt da mezarlardır. Büyük Menderes Havzası'nda Erken Tunç Çă̆ı II'ye tarihlenen mezarlar Aphrodisias ve Kusura'da saptanmıştur. Bu mezarlardaki gömü şeklinde bir değişim meydana gelmemiş, Aphrodisias'da küp gömü ve urne şeklinde kavanoz gömü, Kusura'da ise küp gömüler kullanılmaya devam edilmiştir.

Erken Tunç Çă̆ı II'de Bau Anadolu'daki yerleşim sayısında gözlenen büyük artş, Erken Tunç Çağı III'de azalır. Ancak, Büyük Menderes Havzası'ndaki yerleşimlerin oranı Batı Anadolu'nun diğer yörelerinden daha fazladır. Bu nedenle havzanın kültürel oluşumu hakkında bilgi edinmek mümkündür. Erken Tunç Çağı III'de Aşağı Büyük Menderes'de 4, Orta Büyük Menderes'de 19, Yukarı Büyük Menderes'de de 17 olmak üzere toplam 40 yerleşimin iskan edildiği saptanmıştur. Batı ve Güneybatı Anadolu'daki çok sayıdaki yerleşimde Erken Tunç II'den sonra terk edilmiştir. Yerleşim sayısındaki düşüsün en büyük nedeni Erken Tunç Çağı II'nin sonunda oluşan felakettir. Bu felaketi meydana getiren insanların Luwiler olduğu yönünde çeşitli görüşler ve karşı görüşler vardır. Luwiler hakkında doğrudan bilgi verebilecek yazılı belge eksikliği konunun anlaşılmasını güçleştirmektedir. Ancak sınırlı da olsa bazı veriler kimi noktaların açıklanmasını kolaylaşurmaktadır. İzmir çevresindeki Karabel ve Manisa Akpınar'daki anıtlarda saptanan yazı karakterleri bunların Hitit etkili, Luwi kökenli insanlar tarafından yapılma ihtimalini ortaya koymuştur ${ }^{43}$. Ayrıca son yllarda Troia kazısında ve Metropolis'de bulunan Luwi mühürlerini de dikkate almak gerekmektedir. Büyük Menderes Havzası'nın yukarı kesimlerinde de bu halklarla ilgili iki

42 Lamb 1938, Fig. 2, 3.

${ }^{43}$ H.G.Güterbock "Hittites and Akhaens: a New Look", Proceedings of American Philosophical Society, Vol 128 No:2 (1984), 115, Fig.5; M.Darga, Hitit Sanat, İstanbul, 1992. 183; G.E.Bean, Eskiçağlarda Ege Bölgesi, İstanbul, 1995, 32; A.Salvini-M.Salvini, "Nouveller Considerations Sur Le Relief Rupestre De La Pretendue Niobe Du Mont Sipylen, Collectanea Orientalia 3 (1996), 7 vd.; 
buluntu ele geçmiştir. Biraz daha geç bir döneme tarihlenen bu eserlerden ilki Beycesultan'ın Erken Tunç Çağı'ndan Orta Tunç Çağı'na geçiş evre sinde bulunan kil mühür, diğeri ise Çivril yakınlarında Habib-i Acem höyüğünde ele geçen, literatürde "Çivril Grafitosu" denilen, üzerinde Luwi hiyerogrifinin saptandığı kase parçasıdır ${ }^{44}$. Kil mühür üzerinde i-ha-a (zi-ha-a) şeklinde bir isim geçmektedir. Bu ismin bir şahısa ait olduğu düşünülmektedir $^{45}$. Bu eser Anadolu'nun en eski yazılı belgelerinden biri olma özelliğine de sahiptir. Ayrıca Hitit metinlerinde rastlanan ve Büyük Menderes Havzası'nda lokalizasyonlarını kabul ettiğimiz bazı yerleşimlerin isimleri de Luwice'nin etkisini belgelemektedir. Böylece, Büyük Menderes Havzası'nın en azından orta ve yukarı kesimlerinin İzmir-Manisa çevresi ile birlikte Luwi yayılımı içerisinde yer aldığı ileri sürebilir. Özellikle Beycesultan'ın, Luwi idare merkezlerinden biri olması muhtemeldir. Beycesultan'da yeniden başlatılacak bir kazı pekçok sorunun çözümünün yanında bu konuyla ilgili bilgi de verebilir ${ }^{46}$.

Erken Tunç Çağı II sonunda yaşanan felaket, yerleşim sayısındaki düşüşün yanı sıra maddi kültür ögelerine de yansımıştur. Erken Tunç Çağı II'de doruk noktasına ulaşan havza kültürü Erken Tunç Çağı III'de silik bir sürece girer. Bu dönemde tüm Bat Anadolu hatta Troia'dan Doğu Akdeniz'e kadar uzanan geniş coğrafyada ortak özellikler gösteren genel bir kültür vardır ${ }^{47}$. Özellikle, Erken Tunç III'ün ilk evresi olan III a'da bu kültür havzanın tümünü etkilemiştir. Kuzeybatı Anadolu ve Kuzey Ege Adaları'na özgü bazı ögeler havzada görülmeye başlanmış, bu döneme kadar kesintisiz bir iskanın belgelendiği Beycesultan'da XVI-XIII ve XII-VIII. tabakaları arasında yerleşimde bir boşluk meydana gelmiştir. Erken Tunç Çağı IIIa çanak çömleğinin en önemli özelliği çarkın son derece yoğun kullanılmasıdır. Ancak, el yapımı mallar üretilmeye devam eder. Gaga ağızlı testiler, tabaklar, çift kulplu çanaklar ve depaslar tipik formlardır ${ }^{48}$. Kırmızı ve kahverengi astar hakim mal grubudur.

${ }^{44}$ Mellaart 1955, 80; Mellaart 1958, 24, 81, 97; J.Mellaart, The Archaeology of Ancient Turkey, Londra, 1978, 48.

${ }^{45}$ Mellaart-Murray 1995, 119, 137, Fig.012, Pl.XIIIa.

46 Son yillarda A. Peschow tarafından Bafa Gölü çevresinde sürdürülen araşurmalarda, Beşparmak Dağlarında Luwi hiyerogrifleri içeren bir Hitit kaya anıtuna rastlanmışur. Bu çok yeni buluntu hakkunda bilgi veren A. Peschlow'a bir kez daha teşekkür ederim.

${ }^{47}$ French 1968, 124.

${ }^{48}$ B.Kadish "Excavations of Prehistoric Remains at Aphrodisias, 1968 and 1969", AJA 75 (1971) , 132. 
Erken Tunç Çă̆ı III'ün ikinci yarısında, yani IIIb'de kültürde yeniden bir canlanma gözlenir. Mellaart'ın deyiniyle bu değişim adeta bir rönesans niteliğindedir ${ }^{49}$. İlk evrede, Kuzeybatı Anadolu kökenli kültürel ögelerin havzaya girmesinin ardından bu dönemde yerel kültürel gruplar yeniden oluşmaya başlar. Beycesultan, Kusura ve bir ölçüde de Aphrodisias bu oluşum içerisine girmiştir. Erken Tunç Çağı III'ün ikinci yarısında kırmızı haçlı çanaklar, dışa kıvrılan yuvarlak (boncuk) ağız kenarlı, yivli ağız kenarlı çanaklar, çaydanlıklar ve volüt kulplu kavanozlar ortaya çıkar ${ }^{50}$. Kap formarından bazısında Orta Anadolu benzerlikleri dikkat çekicidir. X. tabakadan itibaren bu benzerlik artar. Bu benzerlik yoğun olarak kırmızı astarlı-çark yapımı mallarda görülür. Mellaart'ın bu dönemdeki değişimi rönesans olarak adlandırmasına karşın çanak çömleğin kalitesinde önceki dönemlere oranla düşüş inkar edilemez. Yerleşim sayısında ve çanak çömlek kalitesinde meydana gelen düşüşün yanı sıra diğer küçük buluntularda da örneğin metal eser sayısında azalma vardır. Bu durum doğal olarak kültürün bütünlüğünden kaynaklanmaktadır. Ancak, Erken Tunç Çă̆ı III'de dokuma ile ilgili alet sayısında dikkati çeken bir artıs meydana gelmiştir. Bunun nedeni dokuma endüstrisindeki gelişmenin yanı sıra dokumaya duyulan talebin artması ve belki de dolaylı olarak nüfusdaki bir artş̧tan hatta iklim değişiminden kaynaklanabilir.

Erken Tunç Çağı III'de mimaride büyük bir yenilik gözlenmez. Önceki dönemlerde olduğu gibi megaron planlı evler gelişerek devam eder ${ }^{51}$. Dönemin ikinci yarısında Aphrodisias'da birbiriyle bağlantılı yerleşim planı ortaya çıkar. Kazılarda bazı kısımları batıdaki bir bağlant duvarıyla birleştirilmiş megaron planlı evler saptanmıştur. Megaron planlı evler Beycesultan'da da en karakteristik örnekleriyle devam eder. Dönemin ölü gömme adetlerine ait bilgiler Aphrodisias ve Kusura kazılarında açı̆̆a çıkarılan küp mezarlara dayanmaktadır.

Orta Tunç Çağı ve ardından gelen Geç Tunç Çă̆ı, Erken Tunç Çă̆ı'na oranla sosyal ve siyasal yapıda büyük değişimlerin yaşandığı dönemlerdir. Bu dönemlerde Büyük Menderes Havzası genelindeki toplam yerleşim sayısında Erken Tunç Çağı'na oranla bir artş̧ meydana gelmiş olsa da bu artuş sadece Yukarı Büyük Menderes Havzası'ndaki merkezlerden kaynaklanmaktadır.

49 Lloyd-Mellaart 1962, 193.

50 Joukowsky 1986a, 371, 404.

51 Bkz.dp.47, 132. 
Eldeki verilere göre Aşağı Büyük Menderes'de Erken Tunç Çağı IIIb'de olduğu gibi 4 merkez, Orta Büyük Menderes'de Erken Tunç Çağı III'deki 19 merkezden yalnızca 10'u bu dönemde de iskan edilmiş, Yukarı Büyük Menderes'de ise yerleşim sayısı 19'dan 28'e yükselmiştir. Bu yerleşimlerden bir kısmı Minos ve geç dönemlere doğru Miken, bir kısmı ise Hitit kültürünün etkisinde kalmaya başlamıştur. Bu etkilerin en önemli sebebi çok uzak mesafeler arasında bile rahatlıkla yapıldığı anlaşılan geniş çaptaki ticaret ve siyasi ilişkilerdir. Ancak, bu ilişkiler sonucunda meydana gelen toplumlar arası kültürel etkilere karşın, havzanın Neolitik Çağ'dan itibaren süregelen kendine özgü çekirdek kültürel yapısı varlığını devam ettirmiştir. Siyasi, ticari ve bunların sonucundaki kültürel ilişkiler, materyal buluntulardaki etkilerin yanında hiç umulmadık bir gelişmenin havzada yaşanmasına neden olmuştur. Bu ilişkiler sonucunda havza yazı ile tanışmıştur. Orta Tunç Çağı'nda Miletos ve Beycesultan'da ilk yazılı eserler ortaya çıkar. Miletos'da bulunan yerel üretim bir vazo üzerindeki yazı, üç işaretli kazıma çizgiden oluşmaktadır. Yapılan incelemelerle bu yazının Linear $A$ türünde olduğu anlaşılmıştır ${ }^{52}$. Diğer eser ise daha önce de belirttiğimiz şekilde Beycesultan'da bat höyükte Erken Tunç'dan Orta Tunç Çağı'na geçiş tabakalarında ele geçen, üzeri hiyerogrif yazılı kil mühürdür. Bu iki eser, yazı türleri farklı da olsa Erken Tunç/Orta Tunç Çă̆ı'ndan itibaren havzada yazının bilindiğini göstermektedir.

Büyük Menderes Havzası'nda Orta Tunç Çağı'nın en önemli yerleşimi Beycesultandır. Beycesultan, 23 hektara ulaşan alanı ve görkemli sarayıyla Orta Anadolu ve Kıta Yunanistan'daki benzerleri gibi büyük bir kent ya da merkezi yerleşim olarak nitelenebilecek durumdadır. Bu dönemde, Orta Anadolu ile Ege Adaları arasında güçlü ticari ilişkiler kurulmuştur. Karahöyük'de ele geçen kil mühürler, kil objeler ve mühür baskıları Ege yerleşimleriyle, Tryns, Nezero ve Lindos'da bulunan bazı figürinler de Hitit örnekleriyle benzerdir. İki bölge arasında gerçekleşen bu ilişkilerin günümüzdekine benzer bir rota izlenerek Büyük Menderes Havzası üzerinden yapılan ticaretle sağlanmış olması güçlü bir ihtimaldir. Havzanın başlangıç noktasında kurulan Beycesultan, bu ticarette kilit yerleşim konumundadır. Havzanın

52 W.D. Niemeier, "1994/95 Yilı Milet, Myken-Minos Dönemi Kazıları”, XVIII. KST I, Ankara, 1997, 532.

W.D.Niemeier, "The Mycenaeans in Western Anatolia and the Problem of the Origins of the Sea Peoples", Mediterranean Peoples in Transition Honor of Trade Dotham, Israel Exploration Society, (Ed.S.Gitin, A.Mazar, E.Stern), Kudüs, 1998, 28. 
aşağı kesiminde, Ege Denizi kıyısındaki liman kenti Miletos da ticaretin Ege yerleşimleriyle olan bağlantısını sağlamış olmalıdır. Miletos ve çevresindeki diğer yerleşimlerde bu döneme ait buluntu yoğunluğu dikkat çekici bir yogunluktadır. Büyük Menderes Havzası vasıtasıyla Orta Anadolu ile Minos arasında yapılan ticarete ek olarak Beycesultan başta olmak üzere havzanın yukarı kesimleriyle Minos-Orta Anadolu, aşağı kesimleriyle de Minos-Miken arasında da ticari ve kültürel ilişkilerin varlığı saptanmıştur. Bu ilişkiler, aşağıda anlatulacağı şekilde mimari ve çanak çömlekde göze çarpar. Havzanın Orta Tunç Çağı çanak çömleği yerel nitelikleri devam ettiren mal gruplarının yanı sıra erken dönemlerde Minos ve Hitit, geç dönemlerde ise Miken etkili mallardan oluşmaktadır. Hitit çanak çömleğine benzer parçalar Beycesultan ve Kusura, bir ölçüde de Aphrodisias'da bulunmuştur ${ }^{53}$. Minos çanak çömleği ise daha çok havzanın aşağı kesimleriyle sınırlı kalmıştur. İlk olarak Erken Tunç Çă̆ı II'de basit bir yerleşime sahne olan Miletos, bu dönemde ayrı bir kültür olarak nitelenebilecek düzeye ulaşır. Bu kültür, Minos kültürü ile İçbatı Anadolu kültürünün bir sentezidir. Ancak, Miletos Orta Tunç Çağı kültürünün etki alanı oldukça sınırlıdır. Coğrafya bu kültürün yayılımda birinci derecede etkin rol oynamıştır. Miletos dışında Kömür Adası, Değirmentepe Mezarlığı ve Didyma bu kültürün izlerini taşıyan yerleşimlerdir. Bu dönemde Miletos'da üretilen yerel mallardan bazıları Beycesultan'ın saray malları olarak adlandırılan mal grubuna benzer. Orta Tunç Çağı çanak çömleğinde çok değişik yüzey özelliğine sahip örnekler bulunmuş olmasına karşın kap formlarının bazısı bir önceki dönemin devamıdır. Havzanın Orta Tunç Çağı çanak çömleği arasında Minyas malları önemli bir grubu oluşturur. Minyas Malları, Bat Anadolu'dan Kıta Yunanistan'a kadar uzanan çok geniş bir coğrafyada üretilmiştir. Bu malların ilk ortaya çıktıkları yörelerden birisi Yukarı Büyük Menderes Havzası olmasına karşın, burada ele geçen Minyas malları, Batı Anadolu'daki benzerlerinden bazı teknik farklar gösterir. Minyas kaplarında tipik renk gridir, ancak Yukarı Büyük Menderes'deki Beycesultan'da gri renkli hiçbir parçaya rastlanmamıştur. Gri renkteki Minyas malları yaptığımız yüzey araşturmalarında Orta Büyük Menderes'deki Dedekuyusu, Küçüktepe (Çakırbeyli), Üsgebi ve Ayaklı'da bulunmuştur. Ayrıca, Minyas mallarının başlıca özelliklerinden birisi, çarkda üretilmeleri olmasına karşın, Beycesultan'da çok sayıda el yapımı Minyas parçasının ele geçmiş-

${ }^{53}$ Lamb 1937, 23 vd.; Lloyd-Mellaart 1965, Fig.P.2:6-12, 12:12, 13:1-12, 24:1,2,5-8,10,14,15, 24,27, 21:11, 2,34:1-3, Joukowsky 1986a, Fig.326:3; 439:1; Mellaart-Murray 1995, 106. 
$\operatorname{dir}^{54}$. Tüm bu noktalar dikkate alınarak Minyas çanak çömleğinin yayılımı yeniden ele alınmalıdır.

Orta Tunç Çağı'nda çanak çömlek dışında metal eserlerin sayısında ve çeşidinde de değişim meydana gelir. Anadolu genelinde gümüş, yoğun olarak kullanılmaya başlanır. Gümüşün kullanımındaki bu artış, Hitit Devleti' nin Batı Anadolu'ya düzenlediği seferlerin çoğaldığı döneme rastlar. Beycesultan tabaka V'deki saray içerisinde de gümüş süs eşyaları ele geçmiştir. Bu eşyalar, gelişmiş bir metalurjinin varlığına işaret ederler. Madeni eserlerdeki artı̧ silahlarda ve marangoz aletlerinde gözlenmektedir. Beycesultan'da marangoz aletlerindeki artışın en büyük sebebi, yapımında büyük miktarda kereste kullanıldığı anlaşılan saray olmalıdır. Doğu höyükte saptanan sarayın sadece 40 odası açığa çıkarılmıştır. Saray, merkezi bir avlu etrafında yükselmektedir. Enaz iki katlı ve sütunlu kabul salonlarından oluşan bu saray, mimarlık gelişiminin doruk noktasına ulaşuğı V. tabakaya aittir. Yapının düzeltilmiş taşdan meydana gelen, keresteyle desteklenmiş son derece sağlam bir temeli vardır ${ }^{55}$. Duvarlar taş ve kerpiçten yapılmış, bazı durumlarda ahşap kirişler yardımcı eleman olarak kullanılmışur. Kereste iskelet, en alttan çatıya kadar bütün yapıyı sarar. Ayrıca, yine keresteden yapılan sütunlar, bu görkemli yapıyı ayakta tutmayı başaran dayanaklardır. Sarayın batı girişine ulaşılan rampanın alt kısmında üç taş stel bulunmuştur ${ }^{56}$. Bu taş steller, Beycesultan ve Kusura'da yüzyıllardır devam ederek adeta dini bir sembol haline gelen pişmiş toprak stel geleneğinin değişime uğramış halidir. Beycesultan stelleri Troia VI'da olduğu gibi yapıyı dış güçlerden, tehlikelerden korumak amacıyla dikilmiş olabilir. Beycesultan sarayı Beycesultan'ın ilişki içerisinde olduğu iki kültürün, Minos ve Orta Anadolu'nun saraylarıyla benzerlik göstermektedir ${ }^{57}$. Minos saraylarının tipik formu olan labirent tarzındaki bitişik plan, bir ölçüde Beycesultan sarayında da uygulanmıştur. Bu sarayda görülen dikdörtgen avlu, değişik boyutlarla Minos sarayında da vardır. Beycesultan sarayı, M.Ö. 1900-1750 arasına tarihlenmekle birlikte, benzer bir inşa tarzının kullanıldığı Minos sarayları M.Ö. 1700'den önceye tarihlenemez. Dolayısıyla, Minos saraylarının Erken Tunç Çağı II mimari elemanlarında olduğu

${ }^{54}$ J.Mellaart, "The Origin of Minyan Ware", V.Türk Tarih Kongresi, Ankara, 1960, 149

${ }^{55}$ Lloyd-Mellaart 1965, 62.

${ }^{56}$ Yakar 1974, 151. 1975, 71 .

${ }^{57}$ J.G.Macqueen, The Hittites and their Contemporaries in Asia Minor, Southampton, 
gibi Beycesultan'dan etkilendiği söylenebilir. Bu mimari etkileşim ticari ilişkiler sonucunda Minos'a ulaşmış olmalıdır.

Beycesultan Orta Tunç Çağı sarayı, yönetici sınıf ve yönetilen toplum yapısını akla getirir. Bu yapılanma bir anlamda havzadaki ilk kent-devlet örgütüdür. Sağlam duvarlarla desteklenen, içerisinde depo ve tapınaklar bulunan sarayda yönetici sınıf ve askerlerin sürekli olarak yaşadığı, halkın ise belirli dönemlerde dinsel ayinler ya da bir tehlikeden korunmak için içeriye alındığı ileri sürülebilir.Saray, yaklaşık M.Ö.1750 yıllarında tahrip edilmiştir. Bu tahribatun Hitit kralı II. Labarnaş'ın (Hattuşiliş I) Arzawa seferi sırasında oluşması muhtemeldir ${ }^{58}$.

Sarayın ortaya çıkarıldığı V. tabakada, steller dışındaki dini mimari hakkında da önemli bilgiler edinilmiştir. Alan R'de kazılan çifte kutsal alan Erken Tunç Çağı'ndaki öncülerinden ve sonraki benzerlerinden bazı noktalarla ayrılmaktadır. Sunak odasının gerisindeki rahip odası ortadan kalkmış, çifte stellerin yerini seromonik ocak ve ateş sunakları almıştır ${ }^{59}$. Bu durum, etnik yapı, dolaylı olarak da dini inanıştaki bir değişimle ilgili olabilir.

Bu dönemin bir diğer yerleşimi olan Kusura'nın Orta Tunç Çağı mimarisinde Hitit etkilerini gözlemek mümkündür. Kusura $\mathrm{C}$ tabakasında ortaya çıkarılan ve "hisar" olarak adlandırılan yapı, plan ve teknik özellikleriyle Hitit örneklerini hatırlatur ${ }^{60}$. Orta Anadolu'daki pek çok yerleşimde belgelenen gelişmiş plan tipi Kusura'da da uygulanmıştır. Havzanın orta kesiminde, Dandalas Vadisi'nde yer alan Aphrodisias'ın oldukça sınırlı mimari kalıntularında Hitit ya da Minos etkili herhangi bir mimari elemana rastlanmamışur. Açma 7, kompleks C'de ortaya çıkarılan megaron tarzındaki yapı, bu plan türünün devamlılığının belgelenmesi açısından önem taşır. Aphrodisias ve Kusura kazıları mimari açıdan Beycesultan'a oranla son derece sınırlı bilgiler vermelerine karşın, Orta Tunç Çă̆ı'nın ölü gömme geleneklerinin bir ölçüde de olsa anlaşılmasını sağlamıştur. Beycesultan'da bu döneme tarihlenebilecek bir mezar bulunamamıştur. Aphrodisias Akropolis Açma 6'da kavanoz gömü içeren mezarlar, Kusura'da ise küp mezarlar saptanmışur.

${ }^{58}$ Lloyd-Mellaart 1965, 73; J.Mellaart, "Western Anatolia, Beycesultan and the Hittites", Mansel'e Armağan I, Ankara, 1974, 496; S.H.Krahmer, Arzawa, Untersuchungen Zuseine Geschichte nach den Hethitischen Quellen, Heidelberg, 1977, 1 vd.

${ }^{59}$ Yakar $1974,154$.

${ }^{60}$ Lamb 1937, Lev.4; Lamb 1938 Lev.78; R. Naumann, Eski Anadolu Mimarlığı, Ankara 1974,384 . 
Orta Tunç Çağı'ndaki yerleşim sayısı Geç Tunç Çağı'nın ilk evrelerinde artş̧ gösterir. Bu artş özellikle Yukarı Büyük Menderes'de çok belirgindir. Geç Tunç Çağı I'de Aşağı Büyük Menderes'de 7, Orta Büyük Menderes'de 16, Yukarı Büyük Menderes'de 33 olmak üzere toplam 56, Geç Tunç Çağı II'de ise Aşağı Büyük Menderes'de 7, Orta Büyük Menderes'de 14, Yukarı Büyük Menderes'de 14 olmak üzere toplam 35 yerleşim iskan görmüştür.

Geç Tunç Çağı'nda havzanın homojen yapısı iyice değișerek, yöresel kültür grupları en yüksek düzeye ulaşır. Beycesultan, Kusura ve Aphrodisias'ın küçük buluntuları arasında önceki dönemlerde de bazı farklar görülmesine karşın Geç Tunç Çă̆ı'nda ilk kez bu kadar belirginleşir. Havzanın yukarı kesimlerinde Orta Tunç Çağı'nda olduğu gibi Hitit, aşağı kesimlerinde ise Miken etkisi devam etmektedir. Miken etkisi Büyük Menderes Ovası'nın doğusuna gittikçe azalır. Orta Tunç Çağı'nda Güneybat Anadolu'daki Minos yerleşimleri, Orta Tunç Çağı sonu ve Geç Tunç Çağı başlarından itibaren yerlerini Miken kolonilerine bırakırlar. Aşağı Büyük Menderes'de yer alan Miletos bu dönemde, Hitit metinlerinde Millawanda/Milawatas olarak geçen, Ahhiyawa Ülkesi'ne dahil önemli bir Miken kolonisi haline gelmiştir. Miletos Geç Tunç Çağı Kültürü, yoğun bir şekilde Miken Kültürü'nün etkisinde kalsa da kendine özgü bazı yöresel özelliklere sahiptir. Bu durum havzada binlerce yıldır süregelen kültürel birikimin sonucudur.

Geç Tunç Çă̆ı'nda havzada üretilen madeni eserlerin sayısında ve çeşidinde aruş meydana gelir. Metal eşya yapımında yüzyıllardır ana maden olarak kullanılan bakır, yerini demire bırakmaya başlar. İğnelere yeni tipler eklenmiş, çok sayıda bıçak ağzı, ok ucu, mızrak ucu, topuz ve kılıç bulunmuştur. Bu kadar değişik tipte metal eşyanın, özellikle silahların, bir anda ortaya çıkması tesadüf olamaz. Cevresel etkilerin yanı sıra Hitit Devleti'nin yöre üzerindeki baskıları ve düzenlediği seferler, havzadaki toplumların silah yapımına verdikleri önemi arturmış olabilir. Bu dönemde demirin silah sanayiindeki tartışılmaz üstünlükleri keşfedilmiştir. Demir aletler Tunç Çağları'ndan itibaren üretilmekle birlikte tavlama tekniği ancak M.Ö. 1400'lerde silahlarda kullanılmaya başlanmıştur. Demir silahlar bakıra karşı baskın bir grup oluşturmaya başlamıssa da demirin işlenmesi için bakırdan daha fazla emek harcandığı dikkate alınmalıdır. Bakır, soğuduğu sırada bile işlenebilen bir maden iken, demirin başlangıç aşamasından bitimine kadar geçen sürede kor halinde olması gerekmektedir. Bu nedenle demir üretimi, seri ve hızhı bir çalışmayı gerektirir. Bu dönemde, demirin kullanımında görülen 
artı̧ dışında bakır, kalay ve her ikisinin karışımından oluşan tunç eser sayısında da küçümsenmeyecek bir artış meydana gelir. Gümüş ise özellikle süs eşyası yapımında tercih edilmiştir.

Geç Tunç Çağı, maden ihtiyacının artuğı bir dönemdir. Hitit'in gücünü ayakta tutabilmek için daha çok silah ürettiği, dolayısıyla metalurjiyi geliştirdiği ve hatta demirden silah yapımında tekel oluşturduğu düşünülebilir. Metalurjideki ilerleme nedeniyle Orta Anadolu ve çevresindeki maden yatakları bir süre sonra maden ihtiyacını karşılayamaz hale gelince Hititler, alternatif maden yatakları aramaya başlamışlardır. Maden ihtiyaçlarını karşılayabilmek için M.Ö. 14. yüzyılın ikinci yarısında Doğu Akdeniz'deki Ugarit kenti ile ticari ilişkiler kurmuşlar ve Kıbrıs'a (Alaşiya) sefer düzenlemişlerdir. Maden ihtiyacını karşılamak için Kıbrıs'a dahi sefer düzenleyen bir devletin aynı ana karada yer alan, zengin bakır ve demir yataklarının bulunduğu Büyük Menderes Havzası'nı gözardı etmesi düşünülemez. Dolayısıyla, Hitit metinlerinde basit nedenlere bağlanan Arzawa ve Ahhiyawa seferlerinin en önemli, belki de tek sebebi birçok savaşta olduğu gibi ekonomik taleplerdir. Maden yataklarının yanı sıra Güney Ege Adaları ve Orta Anadolu arasında yapılan ticaretin gerçekleştiği doğal yollardan birinin Büyük Menderes Havzası'nda bulunması Hitit Devleti'nin yöre üzerindeki emellerini kuvvetlendiren bir başka sebep olarak düşünülebilir. Havzadaki tepe üstü yerleşim sayısının Geç Tunç Çağı'nda çoğalması ve savunulması kolay yüksek kesimlerin tercih edilmesi Hititler'in saldırlarına karşı düşünülmüş bir çözüm olabilir.

Büyük Menderes Havzası'nda yer alan ve lokalizasyonları hakkındaki tartışmaların günümüzde de devam ettiği yerleşimler, Hitit seferlerine karşı direnmişlerse de, Hititler bu seferlerden kazançlı çıkan taraf olmuştur. Hitit yazılı belgeleri havzanın bu döneminin tarihsel coğrafyasının anlaşılmasını sağlamıştur. Bu seferlerde bahsedilen Arzawa Ülkeleri'nden Seha Irmağı Ülkesi, Zippasla, Hariati, Mira Kuwalia'nın ve Ahhiyawa Ülkesi'nin bir bölümünün, Millawanda/Milawatas, Waliwanda, Iyalanda/Iyalanti, Atriya, Pariyana ve Wallarima kentlerinin havza içerisinde yer alması muhtemeldir ${ }^{61}$.

61 J.Garstang, "Hittite Military Roads in Asia Minor", AJA 47 (1943), 42, pl.XVII; J.Garstang-O.R.Gurney, The Geography of the Hittite Empire, Londra, 1959, 78; O.R.Gurney, "Hittite Geography. Thirty Years After", Hittite and Other Anatolian Near Eastern Studies, Honour of Sedat Alp, (Ed.H.Otten-E.Akurgal-H.Ertem-A.Süel), Ankara, 1992, 220; D.F.Easton, "Hittite History and the Trojan War", The Trojan War, Its Historicity and Context, Papers of the First Greenbank Colloquium, (Ed.L.Foxhall-J.K.Davies), Bristol 1984, 29, 30; Marchese 
Son yillarda A. Peschlow'un Beşparmak Dağları'nda saptadığı Luwi hiyerogrifi Mira ülkesinin, dolayısıyla Arzawa ülkelerinin yerlerinin saptanmasında büyük önem taşımaktadır.

Geç Tunç Çağı'na kadar havzada yaşayan toplumların etnik yapısı bilinmemektedir. Antik Yunan kaynakları sayesinde Geç Tunç Çağı ve sonrası halklar hakkında bilgi edinmek mümkün olmuştur. Buna göre Pelasglar, Lelegler ve Karlar'ın Geç Tunç Çağı'nda havzada yaşadıkları anlaşılmaktadır. Bu halklardan Pelasglar Orta Büyük Menderes'de, Lelegler ve Karlar ise biraz daha güneybatıda Aşağı Büyük Menderes ve çevresinde yaşamış olmalıdırlar ${ }^{62}$. Yukarı Büyük Menderes Havzası'nda yaşayan halklar konusunda bilgi yoktur.

Yukarıda da belirtildiği gibi Geç Tunç Çağı'nda havzanın aşağı kesimleri Miken, yukarı kesimleri ise Hitit kültürünün etkisi altunda kalmıştur. Bu etkiyi en iyi çanak çömlek buluntularında görmek mümkündür. Miken etkili çanak çömlek arasında koyu yüzeyli ve dalgalı hath bezemeli ayaklı bardaklar, meyvalıklar, omurgalı çanaklar, bardaklar, kraterler, testiler ve askoslar sayılabilir. Bu kapların en tipik örnekleri Miletos'da bulunmuştur. Dönemin geç evrelerinde Miletos, Kos-Miletos stili olarak adlandırılan ve Rodos başta olmak üzere kıyıya yakın Ege Adaları'nda da görülen bir çanak çömlek türüne sahiptir ${ }^{63}$. Havzanın doğusunda Miken malzemesi yok denecek kadar azdır. Beycesultan'da yalnızca bir Miken parçası bulunmuştur. Orta Büyük Menderes'deki Aphrodisias ise, tabaka kazısında Miken buluntusu veren tek mer$\operatorname{kezdir}^{64}$. Ancak Aphrodisias'da ele geçen Miken malları ithal olmaktan ziyade ithal malların yerel taklididir. Bu merkezlerdeki kazılar dışında, değişik bilim adamlarının ve bizim yaptığımız yüzey araşurmalarında az sayıdaki yerleşimde Miken çanak çömleği bulunmuştur. Bu yerleşimler de havzanın orta ve özellikle aşağı kesimlerinde yoğunlaşmaktadır. Miken çanak çömleği dı-

1976, 68; R.T.Marchese, The Historical Archaeology of Northern Caria, BAR International Series 536,1989, 33.

${ }^{62}$ G.Thomson, Tarihöncesi Ege, (Çev. Celal Üster), İstanbul, 1983, 188; E.M.Melas, "The Dodecanese and West Anatolia in Prehistory: terrelationships Ethnicity and Political Geography", AS 37 (1988), 114; R.T.Marchese, "Carian Notes: Funenary Practices in the Maeander Valley", Anatolica XXII (1996), 227 vd., Peschlow-Bindokat 1996, 22 vd.

${ }^{63}$ C.Gates, "Defining Boundaries of a State: The Mycenaeans and Their Anatolian

Frontier". Politeia, Society and State in the Aegean Bronze Age, AEGAEUM 12, (Ed. R. Laffineur and W.D. Niemeier), Heidelberg, 1995, 285.

${ }^{64}$ Marchese 1976, 411 
şında havzanın yukarı ve yine sınırlı olarak da orta kesimlerinde Hitit çanak çömleği benzeri parçalar bulunmuştur. Görüldüğü gibi Orta Büyük Menderes Havzası, bulunduğu coğrafi konumu nedeniyle batudan gelen Miken ve doğudan gelen Hitit etkilerinin arasında kalarak her iki kültürden de sınırlı bir şekilde etkilenmiştir. Bir saptama yapmak gerekirse, Hitit benzeri malların havzada dağılımı Arzawa Ülkeleri'nin, Miken mallarının dağılımı ise Ahhiyawa Ülkesi'nin lokalize edildiği coğrafyada yoğunlaşmaktadır. Böylece Hitit metinlerinin dışında arkeolojik malzemeler de tarihsel coğrafyanın biçimlenmesine katkı sağlamaktadır. Ancak, Yukarı Büyük Menderes Havzası'nın Geç Tunç Çağı boyalı çanak çömleğinde Hitit etkisi gözlenmesine karşın özellikle formlar önceki dönem örneklerinin büyük ölçüde devamıdır. Güneybatı Anadolu'da Yukarı Büyük Menderes Havzası'ndan daha ötede Gavurtepe ve Sardes dışında Hitit benzeri çanak çömleğin ele geçtiği en önemli merkez Bayraklıdır. Bayraklı'nın II. binyıl çanak çömleği tam olarak yayınlandığı taktirde Büyük Menderes Havzası'nda bulunan Hitit benzeri çanak çömlek daha iyi yorumlanabilecektir ${ }^{65}$.

Havzanın Geç Tunç Çağı mimarlığı hakkında Beycesultan, Kusura ve Miletos kazıları bilgi vermektedir. Beycesultan Geç Tunç Çă̆ı yapılarının en önemlisi Orta Tunç Çağı sarayının bir tür kopyası olan ve "küçük saray" olarak adlandırılan yapıdır ${ }^{66}$. Doğu tepede bulunan bu yapı, birbiriyle bağlantılı çok sayıda oda ve avludan meydana gelir. Benzerleri Pylos, Mykenai ve Tiryns'de ortaya çıkarılan saray, Geç Tunç Çağı'nda da Orta Tunç Çă̆ı'nda olduğu gibi yönetici bir sınıfın varlığını düşündürmektedir. Beycesultan'ın Geç Tunç Çağı tabakalarında çok sayıda ev ve kutsal alan açığa çıkarılmıştur. Kutsal alanların devamlılığı dinsel düşüncelerin değişmediğini gösterir. Beycesultan'da kutsal alanlar adeta bir gelenek halinde ikiz mekanlar olarak inşa edilmiştir. Yukarı Büyük Menderes'deki diğer yerleşim Kusura'da yapılan kazılar da dönem mimarlığı hakında bilgi vermektedir ${ }^{67}$. Bu dönemde inşa edilen ve kazıcılar tarafindan "pillar shrine" olarak adlandırılan kutsal alanda boğa başı şeklinde bir stel bulunmuştur. Bu stel, daha önce de belirtildiği gibi, Anadolu'da kökeni Neolitik Çağ'a kadar uzanan ve havzada Erken Tunç Çağı IIIb'de şekillenen boğa kültünün bir uzantusıdır.

${ }^{65}$ E.Akurgal, "Bayraklı Kazısı: Ön Rapor", DTCF Dergisi 8 (1950), 1 vd (Türkçe), 52 vd. (Almanca).

${ }^{66}$ Lloyd 1972, 7 vd.

${ }^{67}$ Lamb 1937, 89. 
Aşağı Büyük Menderes'de yer alan Miletos, bu dönemin sivil ve askeri mimarisine ait izler taşımaktadır. Havzada ilkin Geç Kalkolitik Çağ'da kullanılan megaron tarzı, Miletos'da Geç Tunç Çağı evlerinde ve birleşik plana sahip bazı yapılarda da uygulanmıştır. Ancak, Miletos'un bu döneme tarihlenen mimari kalıntularından en önemlisi sur duvarıdır ${ }^{68}$. Kazılarda bu duvarın $70 \mathrm{~m}$.lik bir kısmı açığa çıkarılmış ve her $14 \mathrm{~m}$.de bir burç yerleştirildiği saptanmıştur. Duvarın bulunduğu dönemde Miletos, Hititler'le ilişki içerisinde fakat Ahhiyawa Ülkesi'ne dahil bir yerleşimdir. Bu sur duvarı, Miken'den çok Hitit etkisi göstermektedir. Özellikle kazamatlar, Hitit mimarlığının Milet'e yansıyan etkileridir. Duvarın yapılma sebebi de en az yapıldığı dönem kadar önemlidir. Duvar, Miletos'u karadan, özellikle doğudan gelebilecek tehlikelerden korumak için yapılmış olmalıdır. Surun boyutları tehlikenin büyüklüğünü belgelemektedir. Geç Tunç Çağı'nda Anadolu'da bu denli büyük silahlı tek güç Hitit ordusudur. Hititler'in, Güneybatı Anadolu ve Ahhiyawa üzerine düzenlediği seferler dönemin en önemli askeri olaylarıdır. Elimizdeki bilgilere göre Ahhiyawa'nın büyük bir surla korunmasını gerektirecek güçte yerel bir düşman devlet de yoktur. Dolayısıyla bu duvarın Hitit tehlikesine karşı yapılmış olması muhtemeldir. Miletos, mimarlık kalıntıları dışında havzanın aşağı kesimlerinin ölü gömme adetleri hakkında da bilgi vermektedir. Miletos yakınlarındaki Değirmentepe mezarları Miken etkili oda ve kaya mezarlarından oluşmaktadır. Benzerleri Güneybatı Anadolu kıylarında ve karşıdaki adalarda görülen bu mezarlar, havzanın aşağı kesimlerindeki Miken etkisini gözler önüne sermektedir.

\section{DEĞERLENDIRME:}

Büyük Menderes Havzası'nın coğrafi kesimlerı ve tarihsel dönemleri arasında yerleşim sayısındaki farklılığın yanı sıra yerleşimlerin niteliklerinde ve boyutlarında da bazı farklılıklar vardır. Havzada en fazla prehistorik yerleşimin belgelendiği Yukarı Büyük Menderes'deki höyüklerin kapladıkları alan oldukça geniş, Aşağı ve Orta Büyük Menderes'deki az sayıdaki höyük ise çok daha küçük boyuttadır. Yukarı Büyük Menderes Havzası'nda tepe üstü yerleşim sayısı azdır. Oysa, havzanın özellikle orta kesimlerinde Erken Tunç Çağı III'den itibaren tepeler yerleşim yeri olarak şeçilmeye başlanmış, Orta Tunç Çă̆ı sonları ve Geç Tunç Çağı'nda da bu durum devam etmiştir. Havzadaki düz yerleşimler hakkında yeterli bilgi yoktur.

${ }^{68}$ Naumann 1975, ek bölüm. 
Yüzey buluntularının incelenmesi sonucunda bazı yerleşimlerin uzun süreli iskan gördüğü, bazısının ise çok kısa sürede terk edildiği anlaşılmaktadır. Örneğin, havzanın en önemli yerleşimi olan Beycesultan, Geç Kalkolitik Çă̆'dan Bizans Dönemi'ne kadar -kısa süreli aralar dışında- binlerce yıl neredeyse kesintisiz bir iskana sahne olmuştur. Beycesultan'ın çok yakınında yer alan Ömerköy Höyüğü ise sadece Geç Kalkolitik Çağ'da iskan edilmiştir. Beycesultan gibi uzun süreli ve geniş ölçekli yerleşimler, çevrelerinde kendinden daha gelişmiş merkezlerin oluşmasını engellemiş olabilir. Bu durum Yukarı Büyük Menderes'de belirgin bir biçimde görülmektedir. Beycesultan çevresine kurulmuş olan çok sayıdaki yerleşimde kültürel oluşum Beycesultan'dan bağımsız gelişememiş, geniş çaptaki bir coğrafyada ortak kültürel özellikler sergilenmiştir. Bu kültürel oluşumları kültür grupları olarak adlandırmak yanlış olmaz. Geniş bir alanda ortak özellikler sergileyen kültürel grupların içerisinde etki alanları sınırlı yerel kültürlerin oluşmuş olması da mümkündür. Yerel kültürlerin kültürel özellikleri hem birbirlerini etkilemiş, hem de kültür gruplarının gelişimine katkı sağlamıştır.

Büyük Menderes Havzası'nın coğrafi bölgeleri arasındaki yerleşim sayısında ve tiplerindeki farklılığın çeşitli sebepleri vardır. Uzun yıllar boyunca bu farklılığın araşturma eksikliğinden kaynaklandığı, özellikle Aşağı ve Orta Büyük Menderes Havzası'nda araştırmaların havzanın yukarı kesimlerine kıyasla oldukça yetersiz kaldığı kabul edilmekteydi. Gerçekten, özellikle Beycesultan kazısı sırasında çevrede yürütülen yüzey araştırmaları Yukarı Büyük Menderes Havzası'nın yalnızca Bat Anadolu'nun değil tüm Anadolu'nun en iyi araşturılan bölgelerinden birisi olmasını sağlamıştur. Ancak elimizdeki veriler bu durumu yalnızca araşturma eksikliğiyle açıklamaya çalışmanın doğru bir yaklaşım olmadığını ortaya koymaktadır.

Havzanın coğrafi bölümleri arasında yerleşim sayısı ve tipindeki farkların sebeplerinden birisi de jeolojik şartlardır. Büyük Menderes Irmağının getirdiği alüvyon dolgunun havzadaki yerleşimlerin sayısını etkileyici bir sebep olması mümkündür. Alüvyon dolgu nedeniyle havzanın özellikle aşağı kesimlerindeki yerleşimlerin bütününün ya da en azından erken dönem tabakalarının toprak altında kaldığı düşünülebilir. Bu durumu yazılı kaynaklar da desteklemektedir. Örneğin Priene, Strabon'un bildirdiğine göre başlangıçta deniz kıyısında bulunmaktaydı. Ancak Strabon'un yaşadığı dönemde (M.Ö. I. yüzyılın ikinci yarısı) 40 stadialık (yaklaşık $7.5 \mathrm{~km}$.) alan Maiandros'un taşıdığı millerle dolmuş ve böylece Priene kıyıdan uzaklaşmıştır. İlk Pri- 
ene kentinin yeri dahi bilinmemektedir, bugün kalıntılarını gördüğümüz kent ise M.Ö. 4. yüzyılda kurulmuştur ${ }^{69}$. Strabon ırmağın bataklık olan ağzından içeri kürekli teknelerle 30 stadia (yaklaşık $5.5 \mathrm{~km}$.) girildiğinde 12 İon kentinden biri olan Myus'a ulaşıldığını, nüfusun azalması yüzünden bu kentin Miletos'a bağlandığını belirtir ${ }^{70}$. Myus'un M.Ö. 500 'lerde açık bir liman olduğu bilinmektedir ${ }^{71}$. Büyük Menderes'in getirdiği miller sonucunda M.Ö. 3 yüzyılın başında buraya deniz yoluyla ulaşmak olanağı kalmamıştur. M.Ö. 2 yüzyılda ise Myus bir bataklık haline dönüşmüş ve kent terk edilmiştir. Myus'un 5-6 km. kuzeydoğusunda bulunan Özbaşı Köyü civarında yapılan bir sondajda denizde yaşayan organizma kalıntılarına rastlanması Büyük Menderes Irmağı'nın eski halicinin Bağarası ve Söke'nin biraz doğusuna kadar sokulabileceğini ispatlamaktadır ${ }^{72}$. Bugün Bafa Gölü'nün kuzeyinde yer alan Azap Gölü'nün bu eski lagün olduğu tahmin edilmektedir.

Büyük Menderes'in getirdiği millerin kıyının yılda ortalama $6.10 \mathrm{~m}$. ilerlemesine neden olduğu anlaşılmaktadır. Bu oluşum Ege Denizi'ne daha yakın konumda bulunan Miletos'u da fazlasıyla etkilemiş ve Antik Çağ'ın bu önemli körfez kenti şimdi denizden $8 \mathrm{~km}$. içeride kalmışur ${ }^{73}$. Bu eski körfezin içinde yer alan Lade Adası da şimdiki Batmaz Tepeleri'ne dönüşmüştür. Miletos'un bu duruma gelmesi yaklaşık M.S. 6. yüzyılda tamamlanmıştur. Miletos'ta son yıllarda yapılan çalışmalar aslanlı limanın tabanının bugünkü deniz seviyesinden $13 \mathrm{~m}$. aşağıda bulunduğu ortaya çıkarmıştur. Profilin alt kesimlerinde M.Ö.4000'lerden 400'lere kadar uzanan profillere rastlanmışur ${ }^{74}$.

Daha güneyde yer alan Latmos Körfezi de önünün kapanması sonucunda Bafa Gölü'ne (Çamiçi Gölü) dönüşmüştür. Arkeolojik verilere dayanarak M.S. 4. yüzyılda Bafa Gölü'nün önünün tamamen kapandığı bilinmektedir. Göney'in belirttiğine göre Büyük Menderes Irmağı Deltası denize

${ }^{69}$ Eisma 1978, 70, 71.

${ }^{70}$ Ünal Yalçın șimdiye kadar Myus antik kenti olarak bildiğimiz mevkiinin aslında antik bir taş ocağı olduğunu iddia etmektedir. Ü.Yalçın-B.Schröder, "Milet ve Yöresinde Jeoarkeolojik Çalışmalar", VIII. AST, Ankara, 1993, 489.

${ }^{71}$ Herodotos V, 36.

${ }^{72}$ Göney 1975, 53.

${ }^{73}$ Eisma 1978, Fig. 2.

74 Ü.Yalçın, "Milet'te Bilimsel Araştırmalar, 1993", X.Arkeometri Sonuçları Toplantısı, Ankara, 1995, 6. 
doğru ilerlememiş, ırmağın içinde yerleştiği tektonik oluğun bir körfez halindeki batı kısmını doldurmuştur. Buradan da anlaşılacağı gibi Büyük Menderes Deltası denize doğru ilerlemiş bir çıkıntı değildir ve bu özelliğiyle Anadolu'nun diğer önemli deltaları olan Yeşilırmak, Kızılırmak, Seyhan, Ceyhan, Göksu ve Sakarya Irmağı deltalarından farklıdır ${ }^{75}$. Söke Ovası genellikle doğuya doğru genişlemekte ve yükselmektedir. Taşkın ovalarının yüksekliği Sarıkemer Köyü'nün kuzeyinde $8 \mathrm{~m}$., Söke'nin güneyinde ise 10 m.dir. Böylece Büyük Menderes'in getirdiği alüvyon dolgu denizi karaya dönüştürmesinin yanında ova seviyesinin de artmasına yol açmış olmalıdır. Bat Anadolu'da geniş bir coğrafyada karşılaşıldığı şekilde Aşağı Büyük Menderes'in çeşitli kesimlerinde alüvyon dolgunun oluşturduğu birikinti alanları kolaylıkla görülmektedir. Birikintiler, düz yerleşimler ve alçak höyükler üzerinde daha etkili olmuş, bazı durumlarda ova seviyesi yükselerek yerleşimin üst noktasına kadar ulaşmış ve yerleşim ile ova aym seviyeye gelmiştir. Bu konuda daha sağlıklı veriler elde etmek için Așağı Büyük Menderes Havzası'nda Miletos kazı ekibi tarafından gerçekleştirilen Jeoarkeolojik çalışmaların havza içerisinde daha geniş bir alanlarda yaygınlaşturılması gerekmektedir.

Havzanın özellikle aşağı kesimlerindeki Jeomorfolojik çalışmalardan birisi Bochun Ruhr üniversitesinden Bilal Bay tarafından gerçekleştirilmiştir ${ }^{76}$. Bu çalışmaya göre, Ege Denizi, Büyük Menderes Ovası içerisindeki en geniş konumunu günümüzden yaklaşık 3500 yıl önce almıştır. Buna göre deniz yaklaşı Aydın kent merkezinin güneyine kadar sokulmuş ve günümüzde Çine Çayı'yla Büyük Menderes'in birleştiği kesim sınır olmuştur ${ }^{77}$. Belki de iklimdeki değişiklikler sonucundaki deniz seviyesindeki yükselmeler bu durumu meydana getirmiştir.

Havzanın coğrafi kesimleri arasındaki yerleşim sayısı farklılığını incelerken, üzerinde durulması gereken bir başka nokta tahribatur. Aşağı ve Orta Büyük Menderes'deki tahribat, Yukarı Büyük Menderes'den daha fazladır. Büyük Menderes Havzası'nın, 'Büyük Menderes Ovası' olarak adlandırılan aşağı ve orta kesimlerinde tarım, 1950 'lerden itibaren son derece gelişmiş makinelerle yapılmaya başlanmıştur. Böylece, yığma tepeler konumundaki

${ }^{75}$ Göney $1975,52,53$.

${ }^{76}$ B.Bilal Bay, Geoarchaeology, Anthropogenic Soil Erosion and Delta Progradation in the Büyük Menderes Delta (SW-Turkey), 190 pp., Bochum , 1999. (GCA-Verlag). Bilal Bay'a verdiği bilgiler için teşekkür ederim.

77 Bilal Bay'ın bildirdiğine göre bu bilgiler DSí ve õzel sondaj verilerince de doğrulanmaktadır. 
höyükler, diğer arkeolojik anıt ve yerleşimlere oranla daha hızlı ve acımasız bir tahrip sürecine girmiştir. Yöre halkının tarihi eser konusunda son derece bilinçsiz ve duyarsız olması da tahribatu hızlandırmışur. Tahribatı meydana getiren bir başka etmen kaçak kazılardır. Bölgede tarihi eser kaçakçılarının faaliyetleri höyüklerde küçümsenemeyecek tahribatlara yol açmıştır. İçerisinde tümülüs şeklinde mezar bulunabileceği düşüncesiyle hemen her höyüğe çeşitli boyutta çukurlar açılmıştur. Tahribat, bazen o denli büyük boyutlara ulaşmıştur ki höyük boydan boya bir yarma şeklinde ikiye ayrılmış, sonuç olarak 1960'lı yıllarda varlığı bilinen bazı höyükler bile aradan sadece 40 yl geçmesine karşın yok olmuştur. Bu duruma oldukça üzücü bir örnek olarak Hamidiye Höyüğü'nü verebiliriz. French tarafından saptanan ve Neolitik Çağ'a kadar uzanan buluntuların toplandığı höyük tarımsal faaliyetler sebebiyle yok olmuştur ${ }^{78}$.

Havzada en yoğun yerleşimin saptandığı Yukarı Büyük Menderes Havzası'nda havzanın diğer kesimlerine oranla daha zengin orman kaynaklarının ${ }^{79}$ ve maden yataklarının bulunması, çevredeki çok sayıda göl, bu göllerin oluşturduğu ekolojik sistemde avcılık ve balıkçılığın rahatlıkla yapılabilmesi yerleşim yeri olarak tercih edilmesinde rol oynamış olmalıdır. Göllerin bazı dönemlerde kuruması sonucunda, sınırlı olmakla birlikte yüksek kalitede ürün üretilebilecek toprakların ortaya çıkması da göl çevresini yerleşim için cazip hale getirir. Ayrıca Yukarı Büyük Menderes Havzası'ndaki engebeli arazi yapısı sayesinde savunmanın kolaylaşması ve konumuyla Bat Anadolu ile Orta Anadolu arasındaki doğal geçişi oluşturması yerleşim yeri seçiminde önemli diğer hususlardır ${ }^{80}$.

${ }^{78}$ O.Tanındı ve diğerleri, Türkiye Arkeolojik Tahribat Raporu 2000, İstanbul 2001, s.41 Hamidiye.

${ }^{79}$ Yukarı Büyük Menderes Havzası günümüzde giderek azalmakta dahi olsa havzanın diğer kesimlerine kyyasla geniş ormanlık alanlara sahiptir. Beycesultan'ın görkemli II. binyıl sarayında yoğun bir şekilde kereste kullanıldığı bilinmektedir. Lloyd'un hesaplarına göre sarayın en azından kazılan kısmında dört binden fazla ağaç kütük kullanılmış olmalıdır. Ayrıca çevrede, Beycesultan dışında onlarca hōyüğün bulunduğu da dikkate alınmalıdır. Bu yerleşimlerde de kereste kullanıldığı düşünüldüğünde ormanlık alanların günümüzdekinden daha geniş olduğu ileri sūrülebilir.

${ }^{80}$ Ramsay 1960, 50; Günümüzde bölgede kullanılan ana yolların çoğu Dinar ve çevresinde birleşmektedir. Antik Çağlar'da da Yukarı Menderes'in bu uç noktası aymı òzelliğe sahiptir. Bu yollar daha önce de belirttiğimiz gibi Ephesos'dan Magnesia'ya ulaşmakta ve buradan Büyük Menderes Ovası'ndaki şehirleri takip ederek Yukarı Büyük Menderes Havzası'na uzanmaktaydı. Ayrıca daha güneybatıdaki Denizli de uygun yol koşullarıyla oldukça önemli bir konumdadır. Denizli'den batıya doğru giderek Buldan üzerinden Sarıgöl ve dolayısıyla Gediz Havzası'na 


\section{KAYNAKCุA}

Akdeniz 1996 E.Akdeniz, "1995 Yılı Büyük Menderes Ovası ve Çevresi Yüzey Araşturmaları”, XIV.AST, Ankara 1996, 233 vd.

Duru 2000 R.Duru, "Burdur Bölgesi Araşturmaları ve Kuruçay Höyüğü Kazıları", Türkiye Arkeolojisi ve İstanbul Üniversitesi, Ankara 2000, 54 vd.

Eisma 1978 D.Eisma, "Stream Deposition and Erosion by the Eastern Shore of the Aegean", The Enviromental History of the Near and Middle East, Since the Last Ice Age, (Ed.W.C. Brice), Londra, 1978.

French 1968 D.H.French, Anatolia and the Aegean in the Third Millenium B.C., (Basılmamıs Doktora Tezi), Cambridge, 1968.

Gebel 1984 H.G.Gebel, "Ein Weiteres Prahistorisches Felsgesteingerat in Didyma", IstMitt 34 (1984), 29 vd.

Gödecken 1988 K. B.Gödecken, "A Contribution to the Early History of Miletos. The Settlement in Mycenaean Times and its Connections Overseas", Problems in Greek Prehistory, (Ed.E.B. French-K.A.Wardle), Bristol 1988, 307 vd.

Göney 1975 S.Göney, Büyük Menderes Bölgesi, İstanbul, 1975.

Joukowsky 1986 a M.Joukowsky, Prehistoric Aphrodisias I, An Account of the Excavations and Artifact Studies, Louvain-La Neuve, 1986.

Joukowsky 1986 bM.Joukowsky, Prehistoric Aphrodisias, II, An Account of the Excavations and Artifact Studies, LouvainLa Neuve, 1986.

ulaşılır. Bu yol Küçük Menderes Vadisi'ne gitmek için de kullanılabilir. Yolun bir bölümũ Myriokephalon Savaşı'na katulan Bizans Ordusu tarafından da kullanılmıştır. Ulubat yakınlarındaki Lapadium'da toplanan ordu Achyraus (Balıkesir), Thyateria (Akhisar), Sardes, Philadelphia (Alaşehir), Tripolis (Buldan), Hierapolis (Pamukkale), Laodikeia (Eskihisar) üzerinden Khonia/Colassae'ye (Honaz) ulaşmış, buradaki kiliseyi ziyaret ettikten sonra LapisKelainai yoluyla Khomai'ya, oradan da Kufi Çayı Vadisi'ndeki Myriokephalon kalesine varmışlardır.

Ayrınulı bilgi için bkz, N. Khoniates, Historia (Ioannes ve Manuel Komnenos Devirleri), (Çev. F.Ișıltan), Ankara, 1995; K. Turfan, "Myriokephalon Savașı Üzerine Yeni Görüşlerimiz ve Anadolu'nun bir Türk Vatamı Oluşu", Myriokephalon Savaşı, I. ve II. Sempozyum Bildirileri, Çivril Belediyesi Kültür Hizmetleri Yayn No: 1, Denizli 1997, 4-26. 
Joukowsky 1987 M.Joukowsky, "Prehistoric Aphrodisias", Aphrodisias de Carie, Colloque de l'Universite de Lille III, (Ed.J.de la Geniere-K.Erim), Paris 1987, 31 vd.

Lamb 1937 W.Lamb, "Excavations at Kusura Near Afyon Karahisar", Archaeologia 86 (1937), lvd.

Lamb 1938 W.Lamb, "Excavations at Kusura Near Afyon Karahisar", Archaeologia 87 (1938), 217 vd.

Leurquin 1986 J.L.Leurquin, "Prospection de la Vallee du Dandalas Campagne de Fouilles-1982", Prehistoric Aphrodisias I, An Account of the Excavations and Artifact Studies, LouvainLa Neuve, 1986, 725 vd.

Lloyd 1972

S.Lloyd, Beycesultan III/I, Late Bronze Age Architecture, Londra,1972.

Lloyd-Mellaart 1962 S.Lloyd-J.Mellaart, Beycesultan I, The Chalcolithic and the Early Bronze Age Levels, Londra, 1962.

Lloyd-Mellaart 1965 S.Lloyd-J.Mellaart, Beycesultan II, Middle Bronze Age Architecture and Pottery, Londra, 1965.

Marchese 1976 R.T.Marchese, History of Urban Organization in the Lower Maeander River Valley: Regional Settlement Patterns to the Second Century A.D.Newyork, 1976.

Mellaart 1954 J.Mellaart, "Preliminary Report on a Survey of Pre-Classical Remains in Southern Turkey", AS 4 (1954), 175 vd.

Mellaart 1955 J.Mellaart, "Beycesultan Excavations, First Preliminary Report”, AS 5 (1955), 39 vd.

Mellaart 1958 J.Mellaart, "Excavations at Beycesultan, 1957, Pottery from the Lower Levels at Beycesultan", AS 8 (1958), 113 vd.

Mellaart 1961 J.Mellaart, "Early Cultures of the South Anatolian Plateau", AS 11 (1961), 159 vd.

Mellaart 1963 J.Mellaart, "Early Cultures of the South Anatolian Plateau, II", AS 13 (1963), $199 \mathrm{vd.}$

Mellaart-Murray 1995 J.Mellaart-A.Murray, Beycesultan III/II: Late Bronze Age and Phrygian Pottery and Middle and Late Bronze Age Small Objects, Oxford, 1995. 
Peschlow-Bindokat 1996 A.Peschlow-Bindokat, Der Latmos, Eine unbekannte Gebirgslandschaft an der Türkischen Westküste, Mainz, 1996

Peschlow-Bindokat $1999 \quad$ A.Peschlow-Bindokat, "Die Arbeiten des Jahres 1997 in Herakleia am Latmos und Umgebung", XVI. AST II, Ankara 1999, 461 vd.

Ramsay 1960 W.M.Ramsay, Anadolu'nun Tarihi Coğrafyası, (Çev.M.Pektas), İstanbul, 1960.

Schattner1992 T.G.Schattner, "Didymaein Minoische-Mykenischen Fund Platz", AA 1992, 369 vd.

Strabon Geographica, (Çev.A.Pekman), İstanbul, 1993.

Voigtlander 1983 W.Voiglander, "Frühe Funde von Killiktepe bei Milet", IstMitt 35 (1983), 5 vd.

Voigtlander 1986a W.Voigtlander, "Survey bei Akbük" III. AST, Ankara, 1986, 251 vd.

Voigtlander 1986b W.Voigtlander, "Umrisse Eines Vor und Frühgeschichtlichen Zentrums an der Karisch-Ionischen Küste", AA 1986, 613 vd.

Yakar 1974 J. Yakar, "The Twin Shrines of Beycesultan", AS 24 (1974), $151 \mathrm{vd}$.

Yakar 1985 J. Yakar, The Later Prehistory of Anatolia, BAR 268, Oxford, 1985

Yakar 1991 J.Yakar, Prehistoric Anatolia, Tel Aviv, 1991. 
Engin Akdeniz

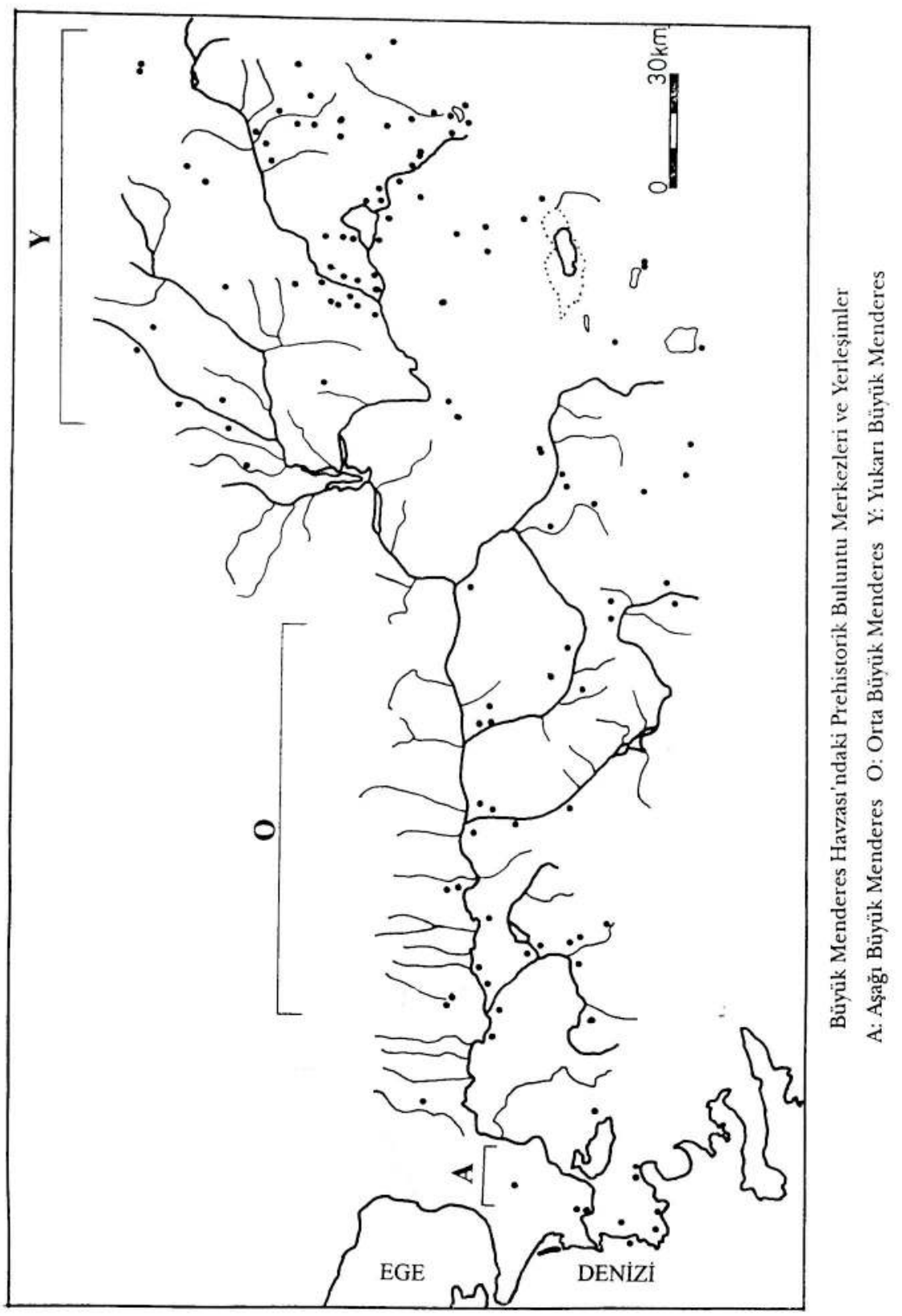




\section{Engin Akdeniz}

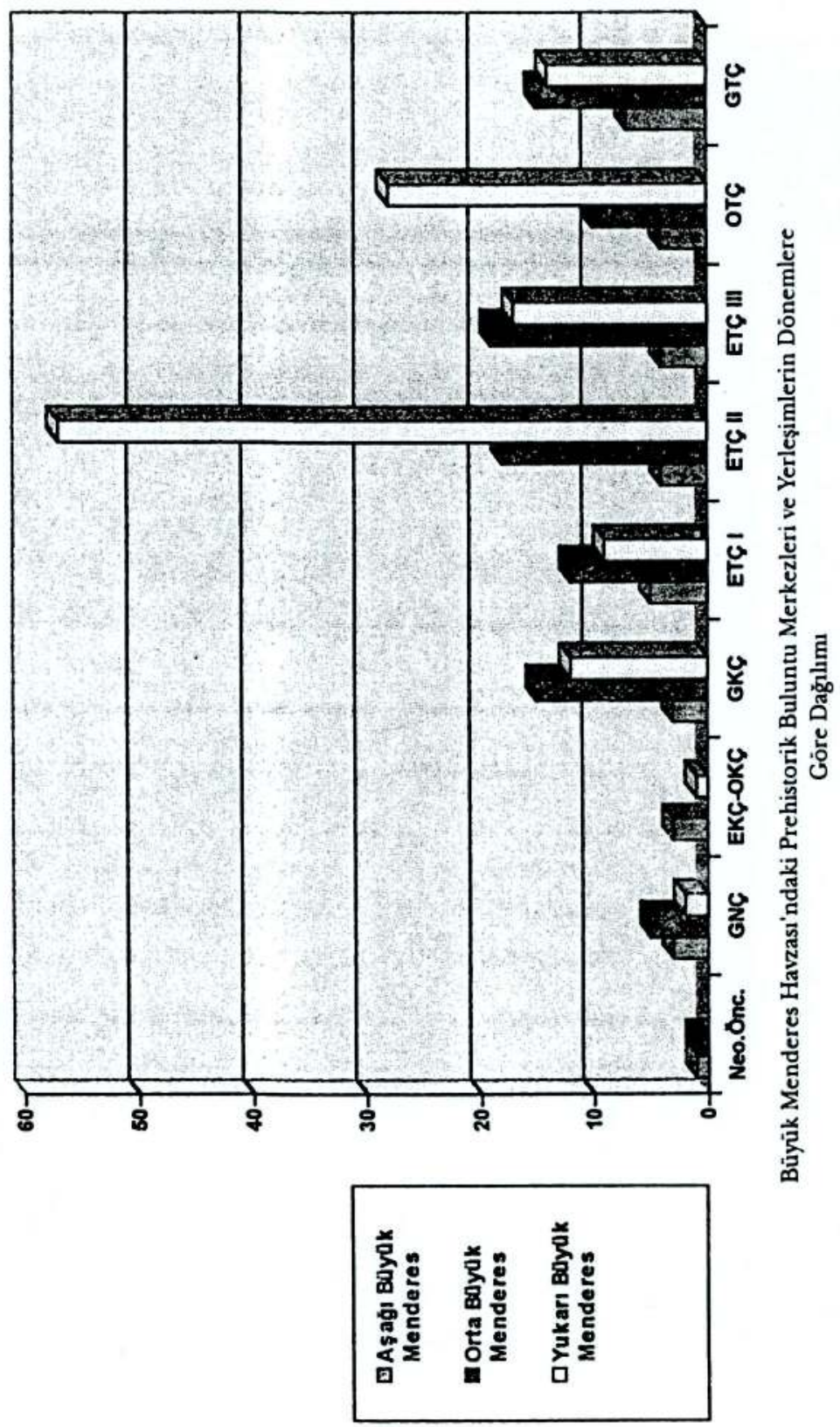

